\title{
Can Labor Regulation Hinder Economic Performance? EVIDENCE FROM INDIA ${ }^{1}$ Timothy Besley And Robin Burgess
}

\begin{abstract}
This paper investigates whether the industrial relations climate in Indian states has affected the pattern of manufacturing growth in the period 1958-92. We show that states which ammended the Industrial Disputes Act in a pro-worker direction experienced lowered output, employment, investment and productivity in registered or formal manufacturing. In contrast, output in unregistered or informal manufacturing increased. Regulating in a pro-worker direction was also associated with increases in urban poverty. This suggests that attempts to redress the balance of power between capital and labor can end up hurting the poor.
\end{abstract}

JEL: H0, H1, I3, J5, K2, L5, L6, O2, O4

\section{INTRODUCTION}

One of the key challenges of development economics is to identify policies that harm or hinder growth, along with an assessment of their effectiveness in poverty reduction. Traditional views of the growth process put development of manufacturing at centre stage in the structural change accompanying economic development. ${ }^{2}$ A casual look at the performance of some of the more successful Asian economies after 1960 adds credence to this view. For example, between 1960 and 1995, manufacturing as a share of GDP grew from 9 percent to 24 percent of GDP in Indonesia, 8 percent to 26 percent in Malaysia and 12.5 percent to 28 percent in Thailand. ${ }^{3}$ All of these countries

\footnotetext{
${ }^{1}$ We are grateful to two anonymous referees, Daron Acemoglu, Roli Asthana, Abhijit Banerjee, Richard Blundell, Lawrence Katz, Stephen Nickell, Rohini Pande, Christopher Pissarides, Andrew Scott, Andrei Shleifer, Michael Smart, Christopher Udry, and a number of seminar and conference participants for useful comments and suggestions. Berta EsteveVolart, Shira Klien, Silvia Pezzini, Marit Rehavi, Pataporn Sukontamarn and Kamakshya Trivedi provided excellent research assistance. The first draft of the paper was written while Robin Burgess was visiting the Massachusetts Institute of Technology which he wishes to thank for support and encouragment. We thank STICERD for financial support.

${ }^{2}$ See, for example, Kaldor [1967] for an early forceful statement of this view.

${ }^{3}$ Figures on manufacturing shares come from various issues of the World Development Indicators, World Bank, Washington D.C.
} 
had strong overall growth performances and saw significant falls in absolute poverty.

In contrast, the Indian economy did not experience a significant expansion of manufacturing as a share of national income. Manufacturing output constituted 13 percent of GDP in 1960 (ahead of the countries listed above) but grew to only 18 percent of GDP by 1995. India's overall growth over this period was also relatively modest and it did not enjoy declines in absolute poverty on a scale witnessed elsewhere in Asia. While this pattern reflects a complex array of phenomena, a key issue is whether specific policy choices can be shown to have played a role.

This paper studies the role of labor market regulation in explaining manufacturing performance in Indian states between 1958 and 1992. Such regulation is frequently cited in explanations of India's poor growth performance over this period. ${ }^{4}$ The charge is that granting excessive bargaining power to organized labor blunted investment incentives and gave India a generally unfavorable business climate. Our data on labor regulation come from looking at state amendments to the Industrial Disputes Act of 1947. While the act was passed at the central level, state governments were given the right to amend it under the Indian Constitution. The emphasis on central planning in India meant that state governments have had limited influence on industrial policy outside the area of industrial relations. We read the text of each amendment (113 in all) and classified each as pro-worker, pro-employer or neutral. This gave a sense of whether workers or employers benefited or whether the legislation had no appreciable impact on either group. Regulation applies to a specific sector - formal manufacturing - smaller firms in informal manufacturing are not covered.

Between 1958 and 1992 registered manufacturing output per capita grew by 3.3 percent per annum in India as a whole. This, however, masks significant variations across states. For example, West Bengal, which had the highest level of registered manufacturing output per capita at the beginning of the period, had fallen to seventh in 1992 - an average decline of 1.5 percent per annum. West Bengal also had the largest body of pro-worker labor regulation over the period. Its performance contrasts with Andhra Pradesh which grew at nearly 6 percent per year over the same period but which enacted pro-employer labor regulation.

We develop an econometric analysis of whether regulation can account for

\footnotetext{
${ }^{4}$ See, for example, Stern [2001] and Sachs, Varshney, and Bajpai, [1999].
} 
the cross-state pattern of manufacturing performance over time. Our results show that pro-worker labor regulation resulted in lower output, employment, investment, and productivity in the formal manufacturing sector. Output in the informal sector increased. We also find that pro-worker labor regulation is also associated with increases in urban poverty.

The paper illuminates long-standing debates about the role of the state in promoting or hindering economic development. While there is now an abundance of cross-country evidence on determinants of growth, relatively little of this identifies robust relationships with policy regimes [see Barro, 1997]. Papers by Hall and Jones [1999] and Acemoglu, Johnson and Robinson [2001] do suggest that the quality of government institutions matter for economic performance. Looking at policies directly is, however, notoriously difficult given that the details of government intervention differ across countries. Djankov, La Porta, Lopez-de-Silanes, and Shleifer [2002] looks at regulations governing the starting of businesses in a cross-section of 85 countries. They find that countries with higher regulation of entry have less impressive performance across an array of social, political and economic indicators. ${ }^{5}$ They find, in particular that greater regulation expands the size of the unofficial economy. They argue that this is in line with a public choice view of regulation as being put in place by officials or insiders intent on extracting rents (see, for example, Stigler [1971], De Soto [1989], and Shleifer and Vishny, [1998]).

Botero, Djankov, La Porta, Lopez-de-Silanes and Shliefer, [2003] code labor regulations in 85 countries, finding that heavier regulation of labor is associated with a larger unofficial economy, lower labor force participation and higher unemployment. Labor regulations are often cited as a determinant of economic performance in OECD countries [see Freeman, 1988; Blanchard, 2000; Nickell and Layard, 2000]. Higher unemployment in Europe vis a vis North America, for example, is often attributed to more 'rigid' labor institutions in the former [Nickell, 1997]. For European countries, Nickell and Layard [2000], argue that, labor market institutions such as unions and social security systems are important drivers of economic performance with strict labor market regulations, employment protection and minimum wages playing a lesser role. Limited institutional change and the difficulty of controlling for other policies and conditions, however, hinders identification. A number of studies interact labor institutions with observable shocks [Blanchard and Wolfers, 1999] or technological change [Card, Kramarz and Lemieux, 1999]

\footnotetext{
${ }^{5}$ India is close to average in this dimension - it is ranked above Indonesia and Japan.
} 
to explore dynamic effects.

Here, we utilize both time and cross-section variation in labor regulation. The relatively long time period (35 years) and the fact that so much of the policy environment is common to the Indian states makes it an ideal testing ground for the effects of regulation on economic performance and welfare. It adds to a growing body of sub-national evidence that labor regulation affects economic performance. For example, Holmes [1998] uses comparisons across U.S. state borders to show that states which enacted pro-business right-towork laws saw increases in manufacturing activity. Bertrand and Kramarz [2002] use time and regional variation in zoning board approvals to look at how these entry regulations affected employment growth in the French retail industry. Evidence from a variety of studies on Latin America also suggest the importance of labor regulation (see the collection of studies in Heckman and Pages [2003]).

The remainder of the paper is organized as follows. In section II we examine how economic performance has varied across different states, trace the evolution of labor market regulation in India, detail how we capture the direction of regulatory change and set out theoretical predictions on the impact of regulatory change on manufacturing performance. Section III contains the empirical analysis of the effect of labor regulation on manufacturing performance. Section IV turns to the welfare consequences of regulation in terms of poverty reduction and section $\mathrm{V}$ concludes.

\section{BACKGROUND}

Table 1 contains the descriptive statistics for the main variables that we use in our analysis. Manufacturing is comprised of two sub-sectors an unregistered (informal) sector of small firms and a registered (formal) sector of larger firms. ${ }^{6}$ During the period of our data, the latter makes up about 9 percent of state output and the former 5 percent. Firms in the registered sector are covered by the Industrial Disputes Act and are included in the Annual Survey of Industries. This provides information on output, employment, wages, investment and productivity at the state level. Firms in the unregistered sector are not covered by labor regulations and are surveyed periodically in National Sample Surveys. Figure 1 shows how registered

\footnotetext{
${ }^{6}$ Specfically, firms are required to register if either (i) they have more than ten employees and electric power or (ii) they have more than twenty employees and do not use electric power.
} 
manufacturing output varies across states. Some states: Andhra Pradesh, Gujarat, Karnataka, Tamil Nadu and Maharashtra show striking growth, while states like Assam, Jammu and Kashmir and West Bengal stagnate (albeit from very different base levels). These patterns are similar if we look at employment.

A great deal of industrial regulation in India has been central. The centerpiece of the planning regime was the Industries (Regulation and Development) Act of 1951 which states that "it is expedient in the public interest that the Union should take under its control the industries in First Schedule" (this lists all the key manufacturing industries at that date). There have been no formal amendments to this act at the state level (see Malik, 1997). We therefore have a situation where industries in different states of India are subject to a common set of industrial policies except in the area of industrial relations. Entry regulation, via licensing and other instruments, for example, is completely controlled by central government.

There has been much concern about the impact of industrial licensing and the use of tariff and non-tariff barriers. It is often suggested that this has led Indian manufacturing to perform poorly relative to other countries (see Singh [1964], Bhagwati and Desai [1970] and Bhagwati and Srinivasan [1975]). In particular, relative to countries in East Asia which experienced rapid manufacturing growth (World Bank, 1993; Bhagwati, 1998). But it is not possible to relate its impact to the patterns of economic development found in Figure 1.

Increasing attention is being paid to the spatial pattern of industrial development in India. A recent survey of about one thousand manufacturing establishments drawn from ten Indian states by Dollar, Iarossi and Mengitsae [2001] suggests that productivity is forty-four percent lower in states judged by managers to have poor business climates. Labor regulation is often singled out as an important element of business climate. Dollar et al [2001] found that managers would be willing to lay-off 16-17 percent of their work force if there was greater labor market flexibility and that this measure of the cost of labor regulation had a significant negative impact on firm level productivity.

\section{II.A Labor Regulation}

India is a federal democracy and under the Indian Constitution of 1949 industrial relations is a concurrent subject. This implies that central and state governments have joint jurisdiction over labor regulation legislation. The key piece of central legislation is the Industrial Disputes Act of 1947 
which sets out the conciliation, arbitration and adjudication procedures to be followed in the case of an industrial dispute. The Act was designed to offer workers in the organized sector some protection against exploitation by employers. The Act is comprised of seven chapters and forty sections, specifying the powers of government, courts and tribunals, unions and workers and the exact procedures that have to be followed in resolving industrial disputes. $^{7}$ It has been extensively amended by state governments during the post-Independence period. It is these amendments that we use to study the impact of labor market regulation on manufacturing performance and poverty.

We code legislation based on our reading of all state level amendments to the Industrial Disputes Act of 1947 from Malik [1997]. There were 113 such amendments since the Act was passed. Thus although all states have the same starting point, they diverged from one another over time. Each amendment is coded as being either neutral, pro-worker or pro-employer. While this method of classification required a number of judgement calls, we found surprisingly few cases of uncertainty. ${ }^{8}$ For the purposes of quantitative analysis, we coded each pro-worker amendment as a one, each neutral amendment as a zero, and each pro-employer amendment as a minus one.

It is useful to give a couple of examples of this procedure. A sample pro-employer reform is from Andhra Pradesh in 1987. Our synopsis is:

"If in the opinion of the state government it is necessary or expedient for securing the public safety or the maintenance of public order or services or supplies essential to the life of the community or for maintaining employment or industrial peace in the industrial establishment it may issue an order which (i) requires employers and workers to observe the terms and conditions of an order and (ii) prohibits strikes and lockouts in connection with any industrial dispute."

This amendment gets a code of minus one in our data. A sample pro-worker

\footnotetext{
${ }^{7}$ The seven chapters cover: (I) definitions; (II) authorities under this Act; (III) reference of disputes to Boards, Courts or Tribunals; (IV) procedures, powers and duties of authorities; (V) strikes and lockouts, lay-off and retrenchment, unfair labour practices; (VI) penalties and (VII) miscellaneous [see Malik, 1997].

${ }^{8}$ In each case, we based this on two independent assessments. Summaries of all amendments and their coding is available at http://econ.lse.ac.uk/staff/rburgess/wp.
} 
reform is from West Bengal in 1980 where our synopsis is:

"The limit of 45 days for workers receiving $50 \%$ of their wages upon being laid off (if they worked for more than a year) is removed."

This gets coded as one in our data. Having obtained the direction of amendments in any given year, we cumulated the scores over time to give a quantitative picture of how the regulatory environment evolved over time. This is our basic regulatory measure used below. ${ }^{9}$

This method classifies states as either "treatment" or "control" states. The latter are states that do not experience any amendment activity in a pro-worker or pro-employer direction over the 1958-1992 period. There are six of these: Assam, Bihar, Haryana, Jammu and Kashmir, Punjab and Uttar Pradesh. Among those that have passed amendments, our method classifies six states Andhra Pradesh, Karnataka, Kerala, Madhya Pradesh, Rajasthan and Tamil Nadu as "pro-employer". This leaves four "pro-worker" states: Gujarat, Maharastra, Orissa and West Bengal. Figure 2 graphs the history of regulatory change across states over the period in question. For the most part, changes are monotonic although some states do move in different directions. We have both pro-worker and pro-employer states among the fast growers.

Pro-worker states on average had high per capita registered manufacturing output in 1960 relative to control states and pro-employer states. However by 1990, there is no statistically significant difference between pro-worker and pro-employer states. Moreover, registered manufacturing output in the pro-employer states has overtaken that in the control states. This pattern is less pronounced when looking at overall output per capita. Other state characteristics such as total taxes per capita, development expenditure per capita, installed electricity per capita and literacy show no significant difference between treatment and control states.

\footnotetext{
${ }^{9}$ In years in which there were multiple amendments, we use an indicator of the general direction of change. So, for example, if there were four pro-worker amendments in a given state and year, we would only code this as plus one rather than plus four. Coding in this manner gives us a total of nineteen changes in our period (see Figure 2). In an Appendix Table we describe the individual state level amendments which lie behind each of these changes. These take a variety of forms covering limits on the ability to strike, changing the rules relating to layoff, retrenchment and closure and giving workers or employers greater power in the procedures for resolving industrial disputes.
} 
Before considering the impact of labor regulation on economic outcomes, we show that the regulation measure is related to the industrial relations climate in a state as measured by work days lost to strikes and lockouts in the registered manufacturing sector. ${ }^{10}$ This may be a key signal to potential investors. Table 2 shows that labor regulation is strongly positively correlated with work days lost to strikes and lockouts per worker. ${ }^{11}$ Columns (2) and (4) show this finding to be robust to including state specific time trends. Thus, regulating in a pro-worker direction appears to be associated with greater disruption of production. This validates our measure as a representation of the industrial relations climate.

\section{II.B Theoretical Considerations}

The defining difference between registered and unregistered firms is scale, with labor regulations affecting only registered firms. It is reasonable to suppose that all firms operate in a common set of factor markets whose prices they treat as parametric. For simplicity, suppose that firms all produce a common manufactured good. There are then two main routes via which labor regulation affects economic performance - a relative price effect and an expropriation effect. While intellectually distinct, they have similar implications for what we expect to find in the data.

The relative price effect is relevant if the effect of labor regulation is to raise the (fixed or marginal) cost of employing laborers. Labor regulation will typically create adjustment costs in hiring and firing labor and in making adjustments in the organization of production. We would expect firms in the registered sector to substitute away from labor (reducing employment) towards other labor saving inputs (including capital if labor and capital are substitutes). Regulation also lowers the firm's optimal output level since it

\footnotetext{
${ }^{10}$ Strikes and lockouts are both important sources of lost working time. There are twice as many work days lost to strikes than to lockouts. There is pronounced variation across states and time - West Bengal, for example, loses twenty five times as many work days to strikes per capita relative to Assam.

${ }^{11}$ We run panel data regressions of the form:

$$
y_{s t}=\alpha_{s}+\beta_{t}+\mu r_{s t-1}+\varepsilon_{s t}
$$

where $y_{s t}$ is work days lost to strikes and lockouts per worker in the registered manufacturing sector, $r_{s t}$ is the regulatory measure, $\alpha_{s}$ is a state fixed effect and $\beta_{t}$ is a year effect. We cluster our standard errors by state to deal with concerns about serial correlation.
} 
raises the marginal cost of production. We would also expect regulation to affect the decision to register. In states where regulations raise labor costs, firms will (other things being equal) resist becoming registered by remaining small. Thus, we would expect to find fewer registered firms along with a higher level of production in the unregistered sector in states that legislate in a pro-worker direction.

The expropriation effect refers to the dynamic implications of labor regulation. By increasing the bargaining power of workers, labor regulation can increase the importance of hold-up problems in investment. ${ }^{12}$ Suppose that firm's invest in anticipation of earning a particular return may face a problem if workers can expropriate part of that return once the capital is sunk. This will serve to discourage investment, even if labor and capital are substitutes. This has similar predictions in terms of output, employment, output and the decision to register as the relative price effect. However, it strengthens the presumption that capital stocks will also be lower. This effect shows why pro-worker labor regulation is similar to insecure property rights for owners of capital as their sunk investments are subject to worker expropriation.

Whether workers benefit from labor regulation is not clear cut. If labor costs rise because firms put in more worker friendly work practices, then it will depend on how these are paid for in terms of lower wages or lower employment. There may also be differential effects on insiders and outsiders. If there is a hold-up problem, then workers should realize that if they have too much bargaining power, they will reduce investment to their own detriment (especially if labor and capital are complements). Whether wages rise or fall is also not clear-cut.

\section{Method And Results}

Our econometric analysis is based on panel data regressions of the form:

$$
y_{s t}=\alpha_{s}+\beta_{t}+\mu r_{s t-1}+\xi x_{s t}+\varepsilon_{s t}
$$

where $y_{s t}$ is a (logged) outcome variable in state $s$ at time $t, r_{s t}$ is the regulatory measure (which we lag one period to capture the gap between enactment

\footnotetext{
${ }^{12}$ Grout [1984] developed one of the first models along these lines. Caballero and Hammour [1998] draw out macro-economic implications.
} 
and implementation $)^{13}, x_{s t}$ are other exogenous variables, $\alpha_{s}$ is a state fixed effect and $\beta_{t}$ is a year fixed effect. We cluster our standard errors by state to deal with concerns with serial correlation (Bertrand, Duflo and Mullainathan, $[2002]){ }^{14}$

The state fixed effect captures state-specific factors such as culture and geography. The year effects capture common shocks such as central government amendments to the Industrial Disputes Act which took place in 1976 and 1982 (see Fallon [1987] and Fallon and Lucas [1993]) as well as other centrally implemented policies.

\section{III.A Basic Results}

Table 3 looks at measures of output per capita and their link to labor regulation. The left hand side variable in column (1) is total state output per capita which does not appear to be correlated with the labor regulation regime. This is reasonable since labor regulation is sector specific and registered manufacturing represents a fairly small part of the Indian economy. Above all, this suggests that labor regulation is not simply a proxy for generally poor government policy. Column (2) looks at agricultural output. A negative effect here would also suggest that our labor regulation is really proxying for other policies. In fact, there is a weak positive effect suggesting that discouraging manufacturing may encourage agricultural production. In contrast, non-agricultural output - which includes manufacturing - is negatively correlated with labor regulation (column (3)). Column (4) shows that there no effect on output in the construction sector, another sector where labor regulation is not applied. ${ }^{15}$

Turning to manufacturing, column (5) shows that the point estimate becomes larger and more significant when focusing on total manufacturing output. Breaking this into registered and unregistered sectors as in columns (6) and (7) of Table 3 provides further confirmation that the effect at work is specific to registered manufacturing. There is now a larger and more significant negative effect on registered manufacturing in column (6). Moreover, for unregistered manufacturing in column (7), we get the opposite sign -

\footnotetext{
${ }^{13}$ Our results are robust to imposing different lags. Our readings of the literature suggests that amendments come into force roughly one year after they are passed.

${ }^{14} \mathrm{We}$ conducted some stationarity tests for panel data of the kind suggested by Madalla and $\mathrm{Wu}$ [1999]. These suggested no difficulty in assuming stationarity.

${ }^{15}$ Over our period construction accounts for 5 percent of total state output and 10 percent of non-agricultural output.
} 
high levels of pro-worker labor regulation have a positive impact on output in this sector. ${ }^{16}$ Thus labor regulation seems to deter formal registration, encouraging firms to remain in the informal sector.

These results make sense. Labor regulation is affecting only that sector where we should expect to see an effect. Since labor regulations are the main regulatory instrument in registered manufacturing under state control, this finding is compelling. Our next tasks are to check the robustness of these findings to a number of other specifications and to expand the set of registered manufacturing performance measures beyond just output.

Table 4 assesses the robustness of the finding that registered manufacturing responds negatively to pro-worker labor regulation. Column (1) replicates the basic result from Table 3. In column (2) we add a number of controls. These are the log of real development expenditure per capita which includes spending on health, education, infrastructure and administration. This helps crudely to measure differences in human capital and infrastructure due to government activities. We also include the log of installed electrical capacity per capita, measured in kilowatts, to capture the capacity of states to generate electricity. It may also be a reasonable proxy for the general state of infrastructure and is positively associated with registered manufacturing output. Finally, the log of the state population is also included as a crude measure of changing labor market conditions within a state. Column (2) shows that the coefficient on labor regulation remains negative and significant when we include these controls.

While these results help to deal with the concern that labor regulation is a proxy for other state level policies, it is possible that some aspects of the policy environment are difficult to measure. As a further robustness check, we therefore add in controls for the political complexion of states on the grounds that policies towards the registered manufacturing sector are likely to be correlated with political outcomes. To this end, we assemble a picture of each state's "political history" as measured by the number of years during our data period that particular political groupings have held a majority of the seats in the state legislature. The relevant groupings for this exercise are: the Congress party, the Janata parties, hard left parties and regional parties. The results are in column (3). They show that greater hard left control of the state legislature depresses growth in registered manufacturing. The

\footnotetext{
${ }^{16}$ The idea that firms migrate to the informal sector to escape regulation is widespread - see, for example, Schneider and Enste [2000].
} 
coefficient on labor regulation does, however, remain negative and significant, even though it is smaller in absolute size. The result is consistent with notion that there are anti-business policies which hard left governments introduce. Nonetheless, the effect of labor regulation remains.

In column (4), we add state specific time trends. In this case, the identification of the effects of labor regulations comes from whether such law changes lead to deviations from pre-existing state specific trends. The effect of labor regulation is no longer apparent. Thus, states with similar patterns of labor regulation also have similar long-term trends. Labor regulation appears therefore to be driving differences in these trends. But this does raise the issue of whether it is possible to separate out effects of labor regulations per se from impacts due to the climate of labor relations such as union power and labor/management hostility which manifest themselves in the trend growth rate. We return to this issue below.

Column (5) addresses the sensitivity of the results to the inclusion of West Bengal. This state is an important case for our analysis since it passed the largest number of pro-worker amendments and has had a declining manufacturing base. However, as column (5) shows, the results hold up even if we exclude it from the regression. ${ }^{17}$ In column (6) we show that the result on unregistered manufacturing is robust to including our control variables and excluding West Bengal.

Table 5 looks at the effect for a variety of other performance measures in registered manufacturing. We report this for a specification that includes the full set of controls. In columns (1) and (2), we look at two measures of manufacturing employment. The first, reported in column (1) is the log of total employees taken from the Annual Survey of Industries. This covers both production workers and those in supervisory or managerial positions. We find states with more pro-worker legislation have lower levels of employment in registered manufacturing. This parallels our findings for output. ${ }^{18}$ Column (2) examines daily employment defined as total worker attendances over a year divided by the total number of days worked by the factory. This measure which, captures the intensity of labor usage, is based

\footnotetext{
${ }^{17}$ We carried out further checks by excluding each of the states and in all cases the coefficient on labor regulation remained negative and significant.

${ }^{18}$ It is also consistent with Fallon [1987] and Fallon and Lucas [1993] who found that strengthening job security regulations via the 1976 and 1982 central government amendments to the Industrial Disputes Act was associated with a reduction in labor demand in firms covered by the regulation but not in small firms uncovered by job security regulations.
} 
on returns submitted by registered manufacturing firms and comes from a separate data source, the Indian Labor Yearbook. ${ }^{19}$ Here again we find a negative and significant impact of labor regulation. Comparing columns (1) and (2) suggests that there is greater adjustment in the intensity of labor usage as opposed to in aggregate employment levels which may be connected to constraints on firing workers and closing down firms [Fallon and Lucas, 1993].

Column (3) of Table 5 considers how earnings per worker are affected by labor regulation. The measure is obtained by dividing the total factory wage bill (which includes all monetary payments to workers) by the number of workers. We find that there is no significant effect of regulation on payments to workers. ${ }^{20}$ This lines up with the fact that theory does not give any clearcut predictions for wages. The bottom line is that workers do not appear to be gaining from pro-worker amendments.

In column (4) of Table 5, we examine fixed capital formation. Labor regulations that increase worker bargaining power are likely to reduce capital formation. The coefficient on labor regulation is consistent with this story. Column (5) shows that the number of registered manufacturing factories is negatively related to pro-worker labor regulation. ${ }^{21}$ Column (6) looks at firm firm efficiency in the form of value added per employee. Value added in firms is lower in which there is more labor regulation. This is consistent with an expropriation effect whereby blunting investment incentives leads to labor regulations being associated with lower productivity in the registered manufacturing sector. ${ }^{22}$

To gauge the economic significance of these findings we look at two extreme cases: Andhra Pradesh as a pro-employer state and West Bengal as a pro-worker state. The coefficients from the basic specifications in Tables 4 and 5 imply that without their pro-employer reforms, Andhra Pradesh would

\footnotetext{
${ }^{19}$ As they are based on submissions these figures are likely to be less reliable those based on the Annual Survey of Industries. They nonetheless serve as a useful robustness check.

${ }^{20} \mathrm{In}$ an earlier version of the, we found that is also true for a number of different measures of earnings drawn from both the Annual Survey of Industries and the Indian Labor Yearbook [see Besley and Burgess, 2002].

${ }^{21}$ This variable captures the net flow of firms in the registered manufacturing sector. It shows that the number of firms is significantly lower in states with more pro-worker regulation, suggesting that pro-worker regulation is either acting as a deterrent to new firms or to firms dying at a faster rate.

${ }^{22}$ The results in Table 5 are robust to excluding West Bengal. However, in common with the output results, they are not robust to including state specific time trends.
} 
have registering manufacturing output which was 72 percent of its actual 1990 level and manufacturing employment that was 73 percent of its 1990 level. Had West Bengal not passed any pro-worker amendments it would have enjoyed a registered manufacturing output that was 24 percent higher than its 1990 level and employment that was 23 percent higher. ${ }^{23}$ Thus, the implied economic magnitudes are sizeable.

Collectively these results paint a consistent picture. ${ }^{24}$ Across the board, our labor regulation measure is correlated with poor economic performance in the registered manufacturing sector. It also leads to a larger informal sector.

\section{III.B Endogeneity}

A remaining concern is that states with larger vested interests in manufacturing at the beginning of the period may have experienced greater pressure to pass pro-worker amendments and may, as a consequence, have experienced

\footnotetext{
${ }^{23}$ Though inclusion of the full set of political and economic controls does reduce the magnitudes of these effects they remain economically important.

${ }^{24}$ As a further control for omitted variables, we have collected information on the efficiency of state high courts in India as measured by annual pendency rates. The pendency rate is constructed by adding the number of cases pending at the beginning of the year to cases filed in the year and dividing this by cases resolved during the year. This measure, which is available only for a shorter time period, 1971 - 1996, may be a determinant of the property rights regime in force in the state. In contrast with our labor regulation variable, it has a significantly negative impact on log agricultural output per capita (the coefficient is -0.105 with a robust t-statistic, adjusted for clustering on state, of 2.57). It also has significant and negative association with non-agricultural output as a whole. Within manufacturing it is negatively correlated with the log of unregistered manufacturing output per capita (the coefficient is -0.458 with a robust t-statistic, adjusted for clustering on state, of 1.69) - the opposite sign from labor regulation variable (the coefficient is 0.098 with a robust t-statistic, adjusted for clustering on state, of 2.35) Thus, court inefficiency is correlated with lower informal sector manufacturing. Unlike labor regulation his efficiency measure is not significantly negatively correlated with the log of output per capita in registered manufacturing. The picture that emerges therefore is one where court efficiency adversely affects economic activity in a wide range of sectors, in particular in the large informal sectors where problems of property rights and law and contract enforcement may be acute. In contrast, labor regulations only negatively affect the sector to which they apply and, in contrast, encourage economic activity in unegistered manufacturing and agriculture. These results help to increase our confidence that our amendments measure is picking up the impact of labor regulation as opposed to of other anti-business policies. The question of how courts work in India and affect economic performance is an important issue for further research.
} 
slower growth. Indeed, theoretical arguments along these lines have been developed in the political economy of development literature. For example Krusell and Rios-Rull (1996) model the idea that political insiders can see development as a threat to their rents and hence lobby for protection. In an Indian context, workers would lobby for stricter labor regulation as a means of extracting a greater share of the surplus from existing investments even though this may deter future investment. Thus, the negative correlation between output and performance is consistent with reverse causation. We now develop two ways of addressing this concern empirically.

As our measure of the extent of vested interests, we take the average level of union membership (union members divided by population) before $1977 .^{25}$ We first use these data to match states that experience labor market reforms (pro-worker or pro-employer) with control states based on the level of unionization. $^{26}$ We then regress labor regulation on the difference between registered manufacturing in a 'treatment' state and that in its matched 'control' state while also including match dummies in the regression.

The results are in columns (1) - (3) of Table 6 . They confirm the effects on registered and unregistered manufacturing output per capita and employment in registered manufacturing per capita that we have found throughout. They add credibility to the findings since they guard against the concern that there is something in the initial condition, rather than the subsequent policy experience, which is driving subsequent performance.

An extension of this idea can also yield an instrumental variable for labor regulation. Looking at Figure 2, it is striking that most of the labor regulation changes take place after 1977. This is no-coincidence. Following Prime Minister Indira Gandhi's declaration of a state of emergency (suspending democratic institutions), the political power of her party (Congress) was significantly and permanently diminished. ${ }^{27}$ There were a number of switches in political control with Congress losing its majority in half of our states

25 The data on union membership are patchy. For example there are no usable data for Jammu and Kashmir. Moreover, there are often gaps in the series. We choose the pre-1977 average to get a better sense of the level of unionization.

${ }^{26}$ See the Data Appendix for details on state matches. We also matched based on initial registered manufacturing output per capita, obtaining similar results.

${ }^{27}$ Declaration of a state of emergency was a response to calls for her resignation after she was found guilty of using illegal practices during the prior election campaign. Between 1975, when emergency was declared, and 1978, when fresh elections were called, the share of congress votes in state assemblies dropped from $60 \%$ to $38 \%$. 
between 1975 and 1978. The most notable example was the left front which gained a majority in West Bengal in 1977 and has remained the majority coalition ever since. The 1947 Industrial Disputes Act represented a piece of Congress legislation which was largely kept intact pre-1977 by Congress dominated state governments. Post-1977 state deviations are likely in part to be a result of changes in political control. And the direction that post-1977 amendments took would depend, in part, on the importance of the initial vested interests (as proxied by union membership). This suggests that the union membership variable interacted with a dummy which equals one after 1977 may pick up the time path of labor regulation.

In addition to union membership, we also use historical patterns of land tenure to develop a further instrument. ${ }^{28}$ The main difference is between those areas in India where land revenue was collected through landlords or not. Banerjee and Iyer (2002) show that these measures have an impact on contemporary patterns of development, particularly agricultural productivity and public good provision. Our motivation for using this variable is the possibility that it is correlated with contemporary patterns of political development. In confirmation of this, we find that areas dominated by non-landlord based revenue collection have larger concentrations of regional parties today, i.e. those that do not have a large role in other states or in the national legislature. In many cases, these parties were the main competitor to the Congress party and hence benefitted politically from the state of emergency. Hence, our instrument interacts the fraction of districts in each state that had non-landlord based revenue collection systems with a dummy variable which equals one after 1977 to mark the persistent shift in political control after the state of emergency.

Column (7) of Table 6 confirms that both of our instruments are correlated with labor regulation $(\mathrm{F}$-statistic $=7.46)$. The union variable is positively correlated with labor regulation while the variable based on the proportion of districts under the non-landlord based agricultural tax system is negatively correlated with labor regulation. ${ }^{29}$ In columns (4), (5) and (6), we report two-stage least squares estimates of the effect of labor regulation

\footnotetext{
${ }^{28}$ We are grateful to Abhijit Banerjee and Lakshmi Iyer for providing this data. For each modern state, the variable that we use is the mean number of constituent districts in British India which had non-landlord based land revenue systems. Its contruction is described in detail in the Data Appendix.

${ }^{29}$ As we discussed above, the second of these is explained by the correlation between this variable and regional party development.
} 
on output and employment using these two variables as instruments. Our results are robust to this instrumentation. Moreover, the Sargan test of over-identification passes comfortably. ${ }^{30}$

The effects in the instrumental variables case are uniformly larger in absolute size. This suggests that, if anything biases could be due to high levels of economic performance generating demand for protecting workers. ${ }^{31}$ Overall, these results increase our confidence that poor performance in registered manufacturing was a consequence rather than a cause of labor regulations.

\section{III.C Disaggregated Evidence}

The evidence presented so far aggregates all registered manufacturing industries together. But Indian states have quite different manufacturing bases. Hence, there might be a suspicion that patterns of specialization affect the direction of regulation in ways that could bias our results. For example, early industrializing states might specialize in slow growing labor intensive industries which spawn stronger vested interests, thereby inducing a negative correlation between pro-worker regulations and manufacturing performance.

In response to such concerns, we present results on disaggregated data which look at the impact of labor regulation at the 3-digit industry level for the period $1980-97 .{ }^{32}$ In line with the analysis above, we investigate the link between performance and labor regulation by running panel regressions of the form:

\footnotetext{
${ }^{30}$ The results are not robust to including state specific time trends. Thus we cannot rule out the possibility that the trends in manufacturing output prior to our data period were important in the subsequent pattern of manufacturing development.

${ }^{31}$ This is consistent with our efforts to investigate whether changes in labor regulations were timed around deviations in manufacturing output changes from their trend. We constructed a measure of "recessions" classified as periods in which output growth falls below trend for two consecutive years. No clear pattern emerged. Recessions actually accompanied pro-firm regulatory changes in five of our eighteen reforms (Andhra Pradesh in 1968, Karnataka in 1988, Madhya Pradesh in 1982, Rajasthan in 1970 and Tamil Nadu in 1982). By contrast, it accompanied pro-worker changes in only three cases (Maharastra in 1974, Orissa in 1983 and West Bengal in 1974).

${ }^{32}$ The data form an unbalanced panel. Our anlaysis retains state industries which remain in the panel for at least ten years and within these industries we restrict our attention to firms which employ more than a hundred workers to get around the problem of smaller firms being excluded from the sample to maintain confidentiality. Using this a definition we have total of 1013 -digit industries in our panel with an average of 68 in a each state. The results we obtain our robust to using a balanced panel (i.e. only retaining state 3-digit industries which remain in the panel over the whole 1980-1997 period).
} 


$$
y_{i s t}=\alpha_{i s}+\beta_{t}+\delta_{i} t+\mu r_{s t-1}+\varepsilon_{i s t}
$$

where $y_{i s t}$ is a (logged) 3-digit industry outcome variable, $r_{s t-1}$ is the labor regulation measure measured at the state level and lagged one period, $\alpha_{i s}$ is a state-industry fixed effect, $\beta_{t}$ is a year effect, $\delta_{i}$ is a dummy variable which is equal to one for industry $i$ and $t$ is a time trend. We cluster our standard errors by state-industry grouping to deal with concerns about serial correlation. Inclusion of the state-industry fixed effect allows us to control for unobserved, time-invariant factors which affect performance at the state 3-digit industry level. Thus, identification is now coming from within state-industry variation. The inclusion of 3-digit industry time trends in the regressions also helps to control for the possibility that industries experience different rates of technological change.

Column (1) in Table 7 confirms the basic result above showing that regulating in a pro-worker direction has a significant and negative impact on registered manufacturing output. Column (2) shows that the results for employment also mirror those for state level analysis - employment growth within 3-digit industries is lower in states which regulated in a pro-worker direction. Column (3) confirms our result on fixed capital - investment in fixed capital is lower in pro-worker versus pro-employer states. Moreover, the magnitude of the coefficients we observe in columns (1) - (3) of Table 7 is similar to those in Tables 4, 5 and 6. Column (4), which looks at the number of registered firms in a three digit industry, lines up with the investment effect in column (3) by suggesting that there is greater entry/lower exit in states that regulate in a pro-employer direction. Column (5) shows that regulating in a pro-worker direction is correlated with lower productivity at the 3 -digit industry level as measured by value-added per employee. ${ }^{33}$

While available only for a shorter time period, these results are very similar to those found for the aggregate data for the period 1958-92. They allay any fears that our results are an artefact of patterns of specialization or technological change in registered manufacturing across Indian states.

\section{Welfare Consequences}

\footnotetext{
${ }^{33}$ Although we are allowing for industry specific time trends, the results do not hold up with state specific trends.
} 
We turn finally to the effect of labor regulation on poverty. This is important for a number of reasons, not least because it may give a sense of where the burden of the effects identified in the last section have been felt. To assess this, we use poverty data from Ozler, Datt and Ravallion [1996]. We focus on urban and rural headcounts which measure the percentage of the population below the Indian urban and rural poverty lines. The econometric specification we use is the same as for manufacturing performance.

We expect the direct effect on poverty to depend on the extent to which the earnings of the poor are derived from registered manufacturing. While we have no direct quantitative estimate of this, it is instructive to consider the correlation between poverty rates and different components of state output in India. To do so, we disaggregated state output into agricultural, registered manufacturing, unregistered manufacturing and "other" (non-agricultural/nonmanufacturing). ${ }^{34}$ We find that for urban poverty, the largest coefficient is on registered manufacturing and "other". ${ }^{35}$ Agricultural output and unregistered manufacturing are not significantly correlated with urban poverty. For rural poverty, there is a significant negative correlation between unregistered manufacturing and poverty and no significant correlation with registered manufacturing. These findings square with the fact that registered manufacturing firms are located mainly in urban areas whereas unregistered manufacturing firms are located in both rural and urban areas.

Given this pattern of correlations, our presumption is that pro-worker regulation is positively correlated with poverty in urban areas - with an effect operating through lowered registered manufacturing output and employment. There is no reason to expect a correlation with rural poverty. Table 8 shows that this is indeed the case. In column (1) we see that labor regulation has no effect on overall poverty. This lines up with our result for overall output. Regulating in a pro-worker direction is, however, associated with higher urban poverty (columns (2)). In column (3) we see that, in line with our expectations, there is no significant effect on rural poverty. This

${ }^{34}$ Specifically, we run

$$
p_{s t}=\alpha_{s}+\beta_{t}+\gamma y_{s t}+\varepsilon_{s t}
$$

where $y_{s t}$ is a vector of disaggregated income measures and $p_{s t}$ is a poverty headcount measure.

${ }^{35}$ We cannot reject the hypothesis that the coefficients on these two output sources are equal. 
is consistent with the majority of registered manufacturing firms being in urban locations. In column (4) we find that the results hold up when we add economic controls to our basic specification from column (2). The labor regulation variable continues to exert a significant positive influence on the urban headcount. It is interesting to note that Congress control and hard left control are associated with higher levels of urban poverty.

Column (5) adds state specific time trends. Once again, this wipes out the effect of labor regulation. This underlines the need to exercise caution in attributing the effects observed in columns (2) and (4) to labor regulations as opposed to interactions of underlying differences in the industrial relations climate with regulations.

In column (6) we see that the effects remain when we run the regression only for years when NSS surveys were carried out. This shows that the result in column (6) is not sensitive to interpolating poverty statistics between years. In column (7) we exclude West Bengal from the regression and continue to observe a positive and significant link between pro-worker labor regulation and urban poverty. The coefficient on labor regulation in urban headcount regressions remains highly stable across the full range of specifications (barring column (5)) in Table $8 .^{36}$

The economic significance of these effects can be gauged by examining what urban poverty would have been in 1990 had states not passed pro-worker or pro-employer amendments using the coefficient from column (2) in Table 8. Our empirical model predicts that, without their pro-employer reforms, then Andhra Pradesh would have urban poverty that was 112 percent of its 1990 level. Similarly, had West Bengal not passed any pro-worker amendments it would have had urban poverty that was 11 percent lower in 1990. This comparison starkly brings out how the direction of regulatory change matters. According to our estimates, there would have been around 640 thousand more urban poor in Andhra Pradesh in 1990 and around 520 thousand less urban

\footnotetext{
${ }^{36}$ To check whether the coefficients in Table 8 are consistent with the entire effect on poverty reduction coming through the effect on registered manufacturing output, we regressed urban poverty on registered manufacturing. This yields a coefficient of -3.4 . The size of the effect implied in Table 3 is 0.8 compared to a coefficient in Table 8 of 2.3. However, despite the apparently larger reduced form effect, these two estimates do lie within the $95 \%$ confidence interval for the compound effect of labor regulation. Nonetheless, the results are suggestive of the possibility of a direct effect of labor regulation on poverty beyond the effect operating through falls in registered manufacturing output. For example, regulations could make it easier for non-poor insiders to exclude poor outsiders from access to jobs in the registered sector.
} 
poor in West Bengal had these states not amended the Industrial Disputes Act. ${ }^{37}$

These welfare results are striking. The battle cry of labor market regulation is often that pro-worker labor market policies redress the unfavorable balance of power between capital and labor, leading to a progressive effect on income distribution. We find no evidence of this here - indeed the distributional effects appear to have worked against the poor.

\section{Conclusions}

This paper has examined the link between regulation and long-run development. The evidence amassed in the paper points to the direction of labor regulation as a key factor in the pattern of manufacturing development in India. Regulating in a pro-worker direction was associated with lower levels of investment, employment, productivity and output in registered manufacturing. It also increased informal sector activity.

The results leave little doubt that regulation of labor disputes in India has had quantitatively significant effects. In India, the hand of government has been at least as important as the invisible hand in determining resource allocation. This has provoked heated debate about which aspects of this role have constituted a brake on development. It is apparent that much of the reasoning behind labor regulation was wrong-headed and led to outcomes that were antithetical to their original objectives.

The paper finds little evidence that pro-worker labor market regulations have actually promoted the interests of labor and, more worryingly, that they have been a constraint on growth and poverty alleviation. Our results have not been able thus far to find any gainers except for the extent to which there may have been capital and labor flows across Indian states in response to policy disparities as they have developed. Our finding that regulating in a pro-worker direction was associated with increases in urban poverty are particularly striking as they suggest that attempts to redress the balance of power between capital and labor can end up hurting the poor.

The fact that our results are not robust to state specific time trends does raise the question of whether the effects that we are picking up are those due to labor regulations per se or the consequences of a poor climate of

\footnotetext{
${ }^{37}$ The urban population of Andra Pradesh and West Bengal were 17.15 and 18.15 million respectively in 1990 .
} 
labor relations - union power and labor/management hostility - which affect the trend rate of growth within a state. This goes to interpretation of the finding. But either way, the analysis suggests that labor market institutions in India have had an important impact on manufacturing development.

The analysis reinforces the growing sentiment that government regulations in developing countries have not always promoted social welfare. The example that we have studied here is highly specific and it is clear that it cannot be used to promote a generalized pro- or anti-regulation stance. Future progress will likely rest on improving our knowledge of specific regulatory policies. Research involving particular country experiences will be an important component of this. Only then can the right balance between the helping and hindering hands of government be found.

\section{REFERENCES}

Acemoglu, Daron, Johnson, Simon and James A. Robinson, "The Colonial Origins of Comparative Development: An Empirical Investigation", American Economic Review; XCI (2001), 1369-1401.

Banerjee, Abhijit and Lakshmi Iyer, "History, Institutions and Economic Performance: The Legacy of Colonial Land Tenure Systems in India," available at http://econ-www.mit.edu/faculty/download_pdf.php?id=517, (2003).

Barro, Robert, Determinants of Economic Growth : A Cross-Country Empirical Study, (Cambridge: MIT Press, 1997),

Besley, Timothy, and Robin Burgess, "Land Reform, Poverty and Growth: Evidence from India," Quarterly Journal of Economics, CXV (2000), 389430 .

Besley, Timothy, and Robin Burgess, "Can Labor Regulation Hinder Economic Performance? Evidence from India", CEPR Discussion Paper 3260, 2002 .

Bertrand, Marianne and Francis Kramarz, "Does Entry Regulation Hinder Job Creation? Evidence from the French Retail Industry" Quarterly Journal of Economics CXVII (2002), 1369-1413

Bertrand, Marianne, Esther DuFlo and Sendhil Mullanaithan, "How Much Should We Trust Differences-in-Differences Estimates?," forthcoming in the Quarterly Journal of Economics CXIX, (2004).

Bhagwati, Jagdishm, titlw in Alhuwalia, Isher and Ian Little (eds) India's Economic Reforms and Development: Essays for Manmohan Singh (Delhi: Oxford University Press, 1998) 
Bhagwati, Jagdish and Padma Desai, India: Planning for Industrialization (Delhi: Oxford University Press, 1970)

Bhagwati, Jagdish and T.N. Srinivasan, Foriegn Trade Regimes and Economic Development (Delhi: McMillan, 1975)

Blanchard, Olivier and Justin Wolfers, "The Role of Shocks and Institutions in the Rise of European Unemployment: the Aggregate Evidence," Economic Journal, CX (2000), C1-C33.

Blanchard, Olivier, ents, product and labor market regulation, and unemployment, lecture 2 in The Economics of Unemployment: Shocks, Institutions, and Interactions, (Cambridge MA: MIT Press, 2003).

Botero, Juan, Simeon Djankov, Rafael La Porta, Florencio Lopez-de-Silanes, and Andrei Shleifer, "The Regulation of Labor," typescript, available at http://rru.worldbank.org/DoingBusiness/Downloads/LaborRegulations/flopslabor.3.pdf, 2003.

Butler, David, Lahiri, Ashok and Roy, Prannoy, India Decides : Elections 1952-1991. (New Delhi : Aroom Purie for Living Media India. 1991).

Caballero, Ricardo J. and Mohamad L. Hammour, "The Macroeconomics of Specificity," Journal of Political Economy, CVI (1998), 724-767.

Card, David, Francis Kramarz, and T. Lemieux "Changes in the Relative Structure of Wages and Employment: A Comparison of the United States, Canada and France" Canadian Journal of Economics, XXXII (1999), 843877.

De Soto, Hernando, The Other Path: The Invisible Revolution in the Third World (New York : Harper \& Row, 1989).

Djankov, Simeon, Rafael La Porta, Florencio Lopez-de-Silanes, and Andrei Shleifer, "The Regulation of Entry," Quarterly Journal of Economics CXVII (2002), 1-37.

Datt, Gaurav and Martin Ravallion, "Growth and Redistribution Components of Changes in Poverty Measures: A Decomposition with Applications to Brazil and India in the 1980s" Journal of Development Economics XXXVIII (1992), 275-295.

Dollar, David, Giuseppe Iarossi and Taye Mengistae, "Investment Climate and Economic Performance: Some Firm Level Evidence from India" mimeo World Bank, 2001.

Fallon, Peter, "The Effects of Labor Regulation upon Industrial Employment in India," World Bank Research Department Discussion Paper No 287, 1987. Fallon, Peter and Robert E.B. Lucas, "Job Security Regulations and the Dynamic Demand for Labor in India and Zimbabwe" Journal of Development 
Economics, XL (1993), 241-275.

Freeman, Richard, "Labor Market Institutions and Economic Performance," Economic Policy, VI (1988), 64-80.

Grout, Paul, "Investment and Wages in the Absence of Binding Contracts: A Nash Bargaining Approach," Econometrica, LII (1984), 449-460.

Hall, Robert E. and Charles I. Jones, "Why Do Some Countries Produce So Much More Output Per Worker Than Others?," Quarterly Journal of Economics, CXIV (1999), 83-116.

Heckman, James and Carmen Pagés, Eds Law and Employment: Lessons from Latin American and the Caribbean, (Chicago: The University of Chicago Press for the NBER, 2003).

Holmes, Thomas J., "The Effect of State Policies on the Location of Manufacturing: Evidence from State Borders," Journal of Political Economy, CVI (1998), 667-705.

Kaldor, Nicholas, Strategic Factors in Economic Development, (Ithaca: Cornell University Press, 1967).

Krusell, Per and Jose-Victor Rios-Rull, "Vested Interests in a positive theory of stagnation and growth," Review of Economic Studies, LXIII (1996), 301321.

Maddala, G.S. and Shaowen Wu, "A Comparative Study of Unit Root Tests with Panel Data and a New Simple Test," Oxford Bulletin of Economics and Statistics, LXI (1999), 631-52

Malik, P.L., Industrial Law (Lucknow: Eastern Book Company, 1997)

Nickell, Stephen, "Unemployment and Labor Market Rigidities: Europe versus North-America," Journal of Economic Perspectives, XI (1997), 55-74.

Nickell, Stephen and Richard Layard, "Labor Market Institutions and Economic Performance," in Orley Ashenfelter and David Card (eds), Handbook of Labor Economics, (Amsterdam: North Holland, 2000).

Ozler, B. Datt, G. and Ravallion, M., "A Data Base on Poverty and Growth in India" mimeo, World Bank, 1996.

Planning Commission, Report on the Expert Group on the Estimation of the Proportion and Number of Poor, (New Delhi: Government of India, 1993)

Sachs, Jeffrey, Varshney, A, and N. Bajpai (eds), India in the Era of Economic Reforms (Delhi: Oxford University Press, 1999)

Sargan, John D., "The Estimation of Economic Relationships Using Instrumental Variables," Econometrica XXVI (1958), 393-415.

Schneider, Friedrich and Dominic Enste, "Shadow Economies: Sizes, Causes 
and Consequences," Journal of Economic Literature, XXXVII (2000), 77114.

Shleifer, Andrei and Vishny, Robert, The Grabbing Hand: Government Pathologies and Their Cures (Cambridge: Harvard University Press, 1998)

Singh, Manmohan, India's Export Trends (Oxford: Clarendon Press, 1964)) Stern, Nicholas, A Strategy for Development, (Washington DC: World Bank, 2001).

Stigler, George, "The Theory of Economic Regulation," The Bell Journal of Economics, (1971) Spring, 3-21.

World Bank The East Asian Miracle, (Oxford: Oxford University Press, 1983).

\section{DATA APPENDiX}

The data used in the paper come from a wide variety of sources. ${ }^{38}$ They cover the sixteen main Indian states listed in Figure 1 and refer mainly to the period 1958-1992. Haryana split from the state of Punjab in 1965. After this date on, we include separate observations for Punjab and Haryana. Variables expressed in real terms are deflated using the Consumer Price Index for Agricultural Laborers (CPIAL) and Consumer Price Index for Industrial Workers (CPIIW). These are drawn from a number of Government of India publications which include Indian Labor Handbook, the Indian Labor Journal, the Indian Labor Gazette and the Reserve Bank of India Report on Currency and Finance. Ozler, Datt and Ravallion [1996] have further corrected CPIAL and CPIIW to take account of inter-state cost of living differentials and have also adjusted CPIAL to take account of rising firewood prices. The reference period for the deflator is October 1973- March 1974. State population data used to express magnitudes in per capita terms and as a control comes from the 1951, 1961, 1971, 1981 and 1991 censuses [Census of India, Registrar General and Census Commissioner, Government of India] and has been interpolated between census years. Separate series are available for urban and rural areas.

\footnotetext{
${ }^{38}$ Our data sets builds on Ozler, Datt and Ravallion [1996] which collects published data on poverty, output, wages, price indices and population to construct a consistent panel data set on Indian states for the period 1958 to 1992. We are grateful to Martin Ravallion for providing us with this data and to Guarav Datt for answering various queries. To these data, we have added information on labor regulation, manufacturing performance, political representation, infrastructure and public finances of Indian states.
} 
The labor regulation variable comes from state specific text amendments to the Industrial Disputes Act 1947 as reported in Malik [1997]. We decided to code each change in the following way: a 1 denotes a change that is pro-worker or anti-employer, a 0 denotes a change that we judged not to affect the bargaining power of either workers or employers and a -1 denotes a change which we regard to be anti-worker or pro-employer. There were 113 state specific amendments coded in this manner. Where there was more than one amendment in a year we collapsed this information into a single directional measure. Thus reforms in the regulatory climate are restricted to taking a value of $1,0,-1$ in any given state and year. To use these data, we then construct cumulated variables which map the entire history of each state beginning from 1947 - the date of enactment of the Industrial Disputes Act.

Data on annual work days lost to strikes and lockouts comes from various issues of the Indian Labor Yearbook, Labor Bureau, Ministry of Labor, Government of India. We divide this by number of workers employed from the Annual Survey of Industries data to get a per worker measure.

State output comes from Estimates of State Domestic Product published by Department of Statistics, Ministry of Planning, Government of India. Output variables are deflated and expressed in log per capita terms. The breakdown of total output into agricultural, non-agricultural and manufacturing output is done under the National Industrial Classification System (NIC) which conforms with the International Standard Industrial Classification System (ISIC). Within manufacturing - registered manufacturing is defined by the Factories Act of 1948 to refer to firms with ten or more employees with power or twenty or more employees without power. Unregistered manufacturing refers to firms below these cutoffs and the size of this sector is appraised by sample surveys carried out by the Department of Statistics.

Figures on employees and workers come from the Annual Survey of Industries, Central Statistical Office (Industrial Statistics Wing), Department of Statistics, Ministry of Planning and Programme Implementation, Government of India. Workers are defined as to include all persons employed directly or through any agency whether for wages or not and engaged in any manufacturing process or in any other kind of work incidental to or connected to the manufacturing process. Employees includes all workers and persons receiving wages and holding supervisory or managerial positions engaged in administrative office, store keeping section and welfare section, sales department as also those engaged in purchase of raw materials etc. or purchase of 
fixed assets for the factory and watch and ward staff. Daily employment figures are from returns submitted from firms under the Factories Act of 1948 which have been analyzed and collated in the Indian Labor Yearbook, Labor Bureau, Ministry of Labor, Government of India. They are obtained by dividing total worker (defined as above) attendances in a year by the number of days worked by the factory.

Earnings are defined to include all remunerations capable of being expressed in monetary terms and also payable more or less regularly in each pay period to workers. It includes (a) direct wages and salary payments, (b) remuneration for period not worked, (c) bonuses and ex-gratia payments paid both at regular and at less frequent intervals. It excludes (a) lay off payments which are made from trust or other social funds set up expressly for this purpose, imputed value of the benefits in kind, (b) employer's contribution to the old age benefits and other social security charges, direct expenditure on maternity benefits and crèches and other group benefits, (c) travelling and other expenditure incurred for the business purpose, are re-imbrued by the employer are excluded. Earnings are expressed in terms of gross value i.e. before deduction for fines, damages, taxes, provident funds, employee's state insurance contribution etc. They come from the Annual Survey of Industries and are expressed in real per worker terms.

Value-added in the registered manufacturing sector is the increment to the value of goods and services that is contributed by the factory and is obtained by deducting the value of total inputs and depreciations from the value of output. The number of factories variable comes from the list maintained by the Chief Inspector of Factories in each state which is updated to take into account both deregistration of firms and new entrants. It thus captures the net flow of firms in the registered manufacturing sector. Fixed capital represents the depreciated value of fixed assets owned by the factory on the closing date of the accounting year. Fixed assets are those which have a normal productive life of more than one year. Fixed capital covers all types of assets new or used or own constructed, deployed for production, transportation, living or recreational activities, hospitals, schools etc for factory personnel. All these measures come from the Annual Survey of Industries.

Total installed electrical capacity of electrical generation plants is measured in thousand kilowatts and come from various issues of the Statistical Abstracts of India, Central Statistical Office, Department of Statistics, Ministry of Planning, Government of India. It is expressed in log per capita 
terms. Development expenditure refers to state spending on economic services (agriculture, rural development, special area programs, irrigation and flood control, energy, industry and minerals, transport and communications, science, technology and environment) and social services (education, medical and public health, family welfare, water supply and sanitation, housing, urban development, labour and labour welfare, social security and welfare, nutrition and relief). The primary source is an annual publication, Public Finance Statistics (Ministry of Finance, Government of India). This information is also collated in the Reserve Bank of India's annual publication Report on Currency and Finance.

The data on political histories comes from Butler, Lahiri and Roy [1991]. This primary data is aggregated into four political groupings which are defined in the text and expressed as shares of the total number of seats in state legislatures. State political configurations are held constant between elections. Political history is measured by the number if years during our data period that particular political groupings have held a majority of the seats in the legislature. In our data period, the relevant groupings are: the Congress party, the Janata parties, hard left parties and regional parties. These groupings contain the following parties (i) Congress Party (Indian National Congress + Indian Congress Socialist + Indian National Congress Urs + Indian National Congress Organization), (ii) Janata parties (Lok Dal+Janata+Janata Dal), (iii) a hard left grouping (Communist Party of India + Communist Party of India Marxist), and a (iv) grouping made up of regional parties.

For our measure of unionization we use the number of union members in a state divided by the state population and averaged over the pre1977 period. The source of this data is the Indian Labor Yearbook, Labor Bureau, Ministry of Labor, Government of India. For the matched estimation we rank states by this variable and then match treatment states to control states with the closest level of pre-1977 unionization. The treatmentcontrol matches are as follows: Andhra Pradesh-Uttar Pradesh, GujaratBihar, Karnataka-Haryana, Kerala-Bihar, Madhya Pradesh-Uttar Pradesh, Maharashtra-Assam, Orissa-Uttar Pradesh, Rajasthan-Uttar Pradesh, Tamil Nadu-Assam, West Bengal-Assam. For our historical land tenure measure we used data from Banerjee and Iyer [2002] who classified the land revenue system imposed in each district of British India as landlord or non-landlord based. To construct our state measure we took the mean value for constituent districts of modern states weighting each by land area of the district. 
Our disaggregated registered manufacturing data come from the Annual Survey of Industries which reports information on production activity in the registered manufacturing sector across the sixteen main Indian states for more than 100 3-digit industries during 1980-97.

The poverty figures we use for the rural and urban areas of India's 16 major states, spanning 1957-58 to 1991-92 were put together by Ozler, Datt and Ravallion [1996]. These measures are based on 22 rounds of the National Sample Survey (NSS) which span this period. The NSS rounds are not evenly spaced: the average interval between the midpoints of the surveys ranges from 0.9 to 5.5 years. Surveys were carried out in the following years 1958, 1959, 1960, 1961, 1962, 1963, 1965, 1966, 1967, 1968, 1969, 1970, 1971, 1973, 1974, 1978, 1983, 1987, 1988, 1990, 1991, 1992. Because other data are typically available on a yearly basis weighted interpolation has been used to generate poverty measures for years where there was no NSS survey. The poverty lines used are those recommended by the Planning Commission [1993]. The headcount measures are estimated from the grouped distributions of per capita expenditure published by the NSS, using parameterized Lorenz curves using a methodology detailed in Datt and Ravallion [1992].

Department of Economics and STICERD

London School of Economics 
Table 1: Descriptive Statistics: 1958 - 1992

\begin{tabular}{lcc}
\hline \hline & & Sean \\
\hline & & \\
\hline Labor regulation & -0.148 & 0.925 \\
Works days lost to strikes per worker & 4.350 & 11.90 \\
Works days lost to lockouts per worker & 1.628 & 6.470 \\
Log registered manufacturing output per capita & 4.252 & 0.796 \\
Log unregistered manufacturing output per capita & 3.900 & 0.513 \\
Log registered manufacturing employment & 12.44 & 1.056 \\
Log registered manufacturing fixed capital per capita & 0.709 & 0.846 \\
Log registered manufacturing value added per employee & -11.72 & 0.497 \\
Urban poverty headcount (percent) & 43.14 & 12.76 \\
Rural poverty headcount (percent) & 50.79 & 14.08 \\
Log develop expenditure per capita & 4.368 & 0.824 \\
Log installed electricity capacity per capita & 6.677 & 1.214 \\
Log state population & 10.31 & 0.727 \\
Congress majority & 12.95 & 7.767 \\
Hard left majority & 0.377 & 1.711 \\
Janata majority & 0.616 & 1.440 \\
Regional majority & 1.284 & 4.070 \\
\hline \hline
\end{tabular}

Notes: The data are for the sixteen main states for the period 1958 - 1992. Haryana split from the Punjab in 1965 and, after this date, we include Haryana as a separate observation. We therefore have a total of 552 possible observations with deviations accounted for by missing data. See the Data Appendix for details on the construction and sources of the variables. 
Table 2: Labor Regulation and Industrial Disputes in India: 1958-1992

\begin{tabular}{|c|c|c|c|c|}
\hline & $(1)$ & $(2)$ & $(3)$ & $(4)$ \\
\hline & $\begin{array}{c}\text { Work days lost to strikes } \\
\text { per worker }\end{array}$ & $\begin{array}{l}\text { Work days lost to strikes } \\
\text { per worker }\end{array}$ & $\begin{array}{l}\text { Work days lost to } \\
\text { lockouts per worker }\end{array}$ & $\begin{array}{l}\text { Work days lost to } \\
\text { lockouts per worker }\end{array}$ \\
\hline Method & OLS & OLS & OLS & OLS \\
\hline Labor regulation $[\mathrm{t}-1]$ & $\begin{array}{l}2.564 * * \\
(2.55)\end{array}$ & $\begin{array}{l}1.732^{*} \\
(1.87)\end{array}$ & $\begin{array}{l}2.108 * * \\
(2.32)\end{array}$ & $\begin{array}{l}0.965 * * * \\
(3.57)\end{array}$ \\
\hline State effects & YES & YES & YES & YES \\
\hline Year effects & YES & YES & YES & YES \\
\hline State time trends & NO & YES & NO & YES \\
\hline Adjusted $\mathrm{R}^{2}$ & 0.08 & 0.07 & 0.14 & 0.15 \\
\hline Observations & 547 & 547 & 514 & 514 \\
\hline
\end{tabular}


Table 3: Labor Regulation and Output in India: 1958-1992

\begin{tabular}{|c|c|c|c|c|c|c|c|}
\hline & $(1)$ & $(2)$ & $(3)$ & (4) & $(5)$ & $(6)$ & $(7)$ \\
\hline & $\begin{array}{l}\text { Log state } \\
\text { output per } \\
\text { capita }\end{array}$ & $\begin{array}{l}\text { Log state } \\
\text { agricultural } \\
\text { output per } \\
\text { capita }\end{array}$ & $\begin{array}{l}\text { Log state } \\
\text { non- } \\
\text { agricultural } \\
\text { output per } \\
\text { capita } \\
\end{array}$ & $\begin{array}{l}\text { Log state } \\
\text { construction } \\
\text { output per } \\
\text { capita }\end{array}$ & $\begin{array}{l}\text { Log total } \\
\text { manufacturing } \\
\text { output per } \\
\text { capita }\end{array}$ & $\begin{array}{l}\text { Log registered } \\
\text { manufacturing } \\
\text { output per } \\
\text { capita }\end{array}$ & $\begin{array}{c}\text { Log } \\
\text { unregistered } \\
\text { manufacturing } \\
\text { output per } \\
\text { capita } \\
\end{array}$ \\
\hline Method & OLS & OLS & OLS & OLS & OLS & OLS & OLS \\
\hline Labor regulation [t-1] & $\begin{array}{r}-0.002 \\
(0.14)\end{array}$ & $\begin{array}{l}0.019 * \\
(1.81)\end{array}$ & $\begin{array}{c}-0.034^{*} \\
(1.69)\end{array}$ & $\begin{array}{l}-0.019 \\
(0.29)\end{array}$ & $\begin{array}{c}-0.073 * * \\
(2.05)\end{array}$ & $\begin{array}{c}-0.186^{* * *} \\
(2.90)\end{array}$ & $\begin{array}{c}0.086 * * \\
(2.46)\end{array}$ \\
\hline State effects & YES & YES & YES & YES & YES & YES & YES \\
\hline Year effects & YES & YES & YES & YES & YES & YES & YES \\
\hline Adjusted $\mathrm{R}^{2}$ & 0.93 & 0.84 & 0.95 & 0.76 & 0.93 & 0.93 & 0.75 \\
\hline Observations & 509 & 509 & 509 & 509 & 509 & 508 & 509 \\
\hline
\end{tabular}

Notes: Absolute t statistics calculated using robust standard errors clustered at the state level are reported in parentheses, $*$ significant at $10 \%$, $* *$ significant at $5 \%, * * *$ significant at $1 \%$. Total, non-agricultural, agricultural, total manufacturing, registered manufacturing and unregistered manufacturing output figures are all components of state domestic product and are expressed in log real per capita terms. State amendments to the Industrial Disputes Act are coded 1=pro-worker, $0=$ neutral, -1=pro-employer and then cumulated over the period to generate the labor regulation measure. The data are for the sixteen main states for the period 1958 - 1992. Haryana split from the Punjab in 1965 and, after this date, we include Haryana as a separate observation. We therefore have a total of 552 possible observations with deviations accounted for by missing data. See the Data Appendix for details on the construction and sources of the variables. 
Table 4: Labor Regulation and Manufacturing Performance in India: 1958-1992

\begin{tabular}{|c|c|c|c|c|c|c|}
\hline & $(1)$ & $(2)$ & $(3)$ & $(4)$ & $(5)$ & $(6)$ \\
\hline & $\begin{array}{c}\text { Log registered } \\
\text { manufacturing output } \\
\text { per capita }\end{array}$ & $\begin{array}{c}\text { Log registered } \\
\text { manufacturing output } \\
\text { per capita }\end{array}$ & $\begin{array}{c}\text { Log registered } \\
\text { manufacturing output } \\
\text { per capita }\end{array}$ & $\begin{array}{c}\text { Log registered } \\
\text { manufacturing output } \\
\text { per capita }\end{array}$ & $\begin{array}{c}\text { Log registered } \\
\text { manufacturing output } \\
\text { per capita }\end{array}$ & $\begin{array}{c}\text { Log unregistered } \\
\text { manufacturing output } \\
\text { per capita }\end{array}$ \\
\hline Method & OLS & OLS & OLS & $\begin{array}{c}\text { OLS } \\
\text { [state time trends] }\end{array}$ & $\begin{array}{c}\text { OLS } \\
{[\text { no West Bengal] }}\end{array}$ & $\begin{array}{c}\text { OLS } \\
{[\text { no West Bengal] }}\end{array}$ \\
\hline $\begin{array}{l}\text { Labor regulation } \\
\text { [t-1] }\end{array}$ & $\begin{array}{l}-0.186^{* * *} \\
(2.90)\end{array}$ & $\begin{array}{l}-0.185 * * * \\
(3.65)\end{array}$ & $\begin{array}{l}-0.104 * * * \\
(2.67)\end{array}$ & $\begin{array}{c}0.0002 \\
(0.01)\end{array}$ & $\begin{array}{c}-0.105 * * * \\
(2.59)\end{array}$ & $\begin{array}{c}0.077 * * \\
(2.25)\end{array}$ \\
\hline $\begin{array}{l}\text { Log develop expenditure per } \\
\text { capita }\end{array}$ & & $\begin{array}{c}0.240^{*} \\
(1.88)\end{array}$ & $\begin{array}{l}0.184 \\
(1.55)\end{array}$ & $\begin{array}{l}0.241 * * \\
(2.28)\end{array}$ & $\begin{array}{l}0.208 \\
(1.69)^{*}\end{array}$ & $\begin{array}{c}0.492 * * * \\
(3.39)\end{array}$ \\
\hline $\begin{array}{l}\text { Log installed electricity capacity } \\
\text { per capita }\end{array}$ & & $\begin{array}{l}0.089 \\
(1.47)\end{array}$ & $\begin{array}{l}0.082 \\
(1.51)\end{array}$ & $\begin{array}{l}0.023 \\
(0.69)\end{array}$ & $\begin{array}{l}0.053 \\
(1.21)\end{array}$ & $\begin{array}{c}-0.070 \\
(1.11)\end{array}$ \\
\hline Log state population & & $\begin{array}{l}0.720 \\
(0.75)\end{array}$ & $\begin{array}{l}0.310 \\
(0.26)\end{array}$ & $\begin{array}{r}-1.419 \\
(0.61)\end{array}$ & $\begin{array}{l}0.629 \\
(0.53)\end{array}$ & $\begin{array}{l}-3.724 * * * \\
(3.18)\end{array}$ \\
\hline Congress majority & & & $\begin{array}{c}-0.0009 \\
(0.09)\end{array}$ & $\begin{array}{c}0.020 * * \\
(2.08)\end{array}$ & $\begin{array}{l}-0.002 \\
(0.27)\end{array}$ & $\begin{array}{l}0.017 \\
(0.95)\end{array}$ \\
\hline Hard left majority & & & $\begin{array}{l}-0.050 * * * \\
(2.97)\end{array}$ & $\begin{array}{l}-0.007 \\
(0.77)\end{array}$ & $\begin{array}{c}-0.073 * \\
(1.72)\end{array}$ & $\begin{array}{c}0.154^{*} \\
(1.84)\end{array}$ \\
\hline Janata majority & & & $\begin{array}{l}0.008 \\
(0.34)\end{array}$ & $\begin{array}{r}-0.020 \\
(0.60)\end{array}$ & $\begin{array}{l}0.004 \\
(0.15)\end{array}$ & $\begin{array}{c}0.090 * * \\
(2.20)\end{array}$ \\
\hline Regional majority & & & $\begin{array}{l}0.006 \\
(0.70)\end{array}$ & $\begin{array}{l}0.026 \\
(1.11)\end{array}$ & $\begin{array}{l}0.003 \\
(0.32)\end{array}$ & $\begin{array}{l}0.002 \\
(0.18)\end{array}$ \\
\hline State effects & YES & YES & YES & YES & YES & YES \\
\hline Year effects & YES & YES & YES & YES & YES & YES \\
\hline State time trends & NO & NO & NO & YES & NO & NO \\
\hline Adjusted $\mathrm{R}^{2}$ & 0.93 & 0.93 & 0.94 & 0.95 & 0.94 & 0.80 \\
\hline Observations & 508 & 491 & 491 & 491 & 459 & 459 \\
\hline
\end{tabular}

Notes: Absolute $\mathrm{t}$ statistics calculated using robust standard errors clustered at the state level are reported in parentheses, ${ }^{*}$ significant at $10 \%, * *$ significant at $5 \%,{ }^{* * *}$ significant at $1 \%$. Registered and unregistered manufacturing output are in $\log$ real per capita terms. State amendments to the Industrial Disputes Act are coded 1=pro-worker, $0=$ neutral, $-1=$ pro-employer and then cumulated over the period to generate the labor regulation measure. Log of installed electrical capacity is measured in kilowatts and log development expenditure is real per capita state spending on social and economic services. Congress, hard left, Janata and regional majority are counts of the number of years for which these political groupings held a majority of the seats in the state legislatures. The data are for the sixteen main states for the period 1958 - 1992. Haryana split from the Punjab in 1965 and, after this date, we include Haryana as a separate observation. We therefore have a total of 552 possible observations with deviations accounted for by missing data. See the Data Appendix for details on the construction and sources of the variables. 
Table 5: Labor Regulation and Employment, Investment and Productivity in Registered Manufacturing in India: 1958-1992

\begin{tabular}{|c|c|c|c|c|c|c|}
\hline & $(1)$ & $(2)$ & $(3)$ & $(4)$ & $(5)$ & $(6)$ \\
\hline & $\begin{array}{c}\text { Log registered } \\
\text { manufacturing } \\
\text { employment }\end{array}$ & $\begin{array}{l}\text { Log daily } \\
\text { employment in } \\
\text { registered } \\
\text { manufacturing }\end{array}$ & $\begin{array}{l}\text { Log earnings per } \\
\text { worker in registered } \\
\text { manufacturing }\end{array}$ & $\begin{array}{l}\text { Log fixed capital per } \\
\text { capita }\end{array}$ & $\begin{array}{c}\text { Log number of } \\
\text { factories per capita }\end{array}$ & $\begin{array}{l}\text { Log value added } \\
\text { per employee }\end{array}$ \\
\hline Method & OLS & OLS & OLS & OLS & OLS & OLS \\
\hline Labor regulation & $-0.072 *$ & $-0.285 * * *$ & 0.008 & $-0.120 * *$ & $-0.234 * * *$ & $-0.127 * *$ \\
\hline$[\mathrm{t}-1]$ & $(1.70)$ & $(3.48)$ & $(0.09)$ & $(2.49)$ & $(3.44)$ & $(2.16)$ \\
\hline Log develop expenditure & 0.076 & $0.327^{*}$ & 0.207 & $0.594 * * *$ & 0.229 & $0.262 * *$ \\
\hline per capita & $(0.64)$ & $(1.82)$ & $(1.52)$ & $(2.93)$ & $(1.50)$ & $(2.09)$ \\
\hline Log installed electricity & 0.073 & 0.111 & 0.019 & $0.232 *$ & 0.037 & -0.034 \\
\hline capacity per capita & $(1.34)$ & $(1.51)$ & $(0.34)$ & $(1.82)$ & $(0.95)$ & $(0.45)$ \\
\hline \multirow[t]{2}{*}{ Log state population } & -0.099 & 2.122 & 1.116 & -1.130 & 1.18 & -1.19 \\
\hline & $(0.09)$ & $(1.14)$ & $(0.93)$ & $(0.61)$ & $(0.42)$ & $(0.81)$ \\
\hline \multirow[t]{2}{*}{ Congress majority } & 0.008 & -0.009 & $-0.037 *$ & 0.008 & -0.006 & 0.009 \\
\hline & $(0.61)$ & $(0.39)$ & $(1.66)$ & $(0.43)$ & $(0.36)$ & $(0.73)$ \\
\hline \multirow[t]{2}{*}{ Hard left majority } & -0.028 & $-0.124 * * *$ & 0.0004 & 0.001 & $-0.044 *$ & 0.019 \\
\hline & $(1.43)$ & $(3.93)$ & $(0.01)$ & $(0.05)$ & $(1.81)$ & $(0.90)$ \\
\hline Janata & $0.050^{*}$ & -0.024 & -0.002 & 0.001 & 0.028 & -0.003 \\
\hline Majority & $(1.67)$ & $(0.59)$ & $(0.04)$ & $(0.04)$ & $(0.66)$ & $(0.10)$ \\
\hline \multirow[t]{2}{*}{ Regional majority } & 0.007 & 0.018 & -0.003 & 0.0002 & -0.032 & -0.0001 \\
\hline & $(0.31)$ & $(0.69)$ & $(0.34)$ & $(0.02)$ & $(1.49)$ & $(0.02)$ \\
\hline State effects & YES & YES & YES & YES & YES & YES \\
\hline Year effects & YES & YES & YES & YES & YES & YES \\
\hline Adjusted $\mathrm{R}^{2}$ & 0.98 & 0.91 & 0.75 & 0.80 & 0.90 & 0.64 \\
\hline Observations & 516 & 459 & 513 & 515 & 460 & 435 \\
\hline
\end{tabular}

Notes: Absolute $\mathrm{t}$ statistics calculated using robust standard errors clustered at the state level are reported in parentheses, $*$ significant at $10 \%, * *$ significant at $5 \%, * * *$ significant at $1 \%$. Registered manufacturing employment refers to total employment in factories and daily employment is defined as total worker attendances over a year divided by the total number of days worked by the factory. Earnings per worker is obtained by dividing total annual remuneration by the number of workers. Fixed capital represents the depreciated value of fixed assets owned by the factory on the closing date of the accounting year. The number of factories refers to the number in the registered manufacturing sector in each state where adjustments are made for deregistration and new entrants. Value-added per employee is obtained by deducting the value of total inputs and depreciations from the value of output and dividing this by the number of employees in a factory. State amendments to the Industrial Disputes Act are coded 1=pro-worker, $0=$ neutral, $-1=$ pro-employer and then cumulated over the period to generate the labor regulation measure. Installed electrical capacity is measured in kilowatts and development expenditure is real per capita state spending on social and economic services. Congress, hard left, Janata and regional majority are counts of the number of years for which these political groupings held a majority of the seats in the state legislatures. The data are for the sixteen main states for the period 1958 - 1992 . Haryana split from the Punjab in 1965 and, after this date, we include Haryana as a separate observation. We therefore have a total of 552 possible observations with deviations accounted for by missing data. See the Data Appendix for details on the construction and sources of the variables. 
Table 6 Labor Regulation and Industrial Performance : Dealing with Endogeniety Concerns

\begin{tabular}{|c|c|c|c|c|c|c|c|}
\hline & $(1)$ & $(2)$ & $(3)$ & $(4)$ & $(5)$ & $(6)$ & $(7)$ \\
\hline & $\begin{array}{l}\text { Log registered } \\
\text { manufacturing } \\
\text { output difference }\end{array}$ & $\begin{array}{l}\text { Log unregistered } \\
\text { manufacturing } \\
\text { output difference }\end{array}$ & $\begin{array}{c}\text { Log registered } \\
\text { manufacturing } \\
\text { employment } \\
\text { difference }\end{array}$ & $\begin{array}{c}\text { Log registered } \\
\text { manufacturing } \\
\text { output }\end{array}$ & $\begin{array}{c}\text { Log unregistered } \\
\text { manufacturing output }\end{array}$ & $\begin{array}{l}\text { Log registered man } \\
\text { employ }\end{array}$ & Labor regulation \\
\hline Method & $\begin{array}{l}\text { OLS on matched } \\
\text { differences }\end{array}$ & $\begin{array}{c}\text { OLS on matched } \\
\text { differences }\end{array}$ & $\begin{array}{l}\text { OLS on matched } \\
\text { differences }\end{array}$ & 2SLS & 2SLS & 2SLS & OLS \\
\hline Labor regulation difference & $\begin{array}{c}-0.132 * * * \\
(5.50)\end{array}$ & $\begin{array}{c}0.310^{* * *} \\
(8.20)\end{array}$ & $\begin{array}{c}-0.064^{* *} \\
(2.30)\end{array}$ & & & & \\
\hline Labor regulation [t-1] & & & & $\begin{array}{c}-0.399 * * * \\
(4.02)\end{array}$ & $\begin{array}{l}0.117^{*} \\
(1.80)\end{array}$ & $\begin{array}{c}-0.370 * * * \\
(3.50)\end{array}$ & \\
\hline Mean unionization *post & & & & & & & $0.095 * * *$ \\
\hline 1977 dummy & & & & & & & $(3.52)$ \\
\hline Mean non-landlord*post & & & & & & & $-1.422 * *$ \\
\hline 1977 dummy & & & & & & & $(2.48)$ \\
\hline Match dummies & YES & YES & YES & NO & NO & NO & $\mathrm{NO}$ \\
\hline State effects & NO & NO & NO & YES & YES & YES & YES \\
\hline Year effects & YES & YES & YES & YES & YES & YES & YES \\
\hline $\begin{array}{l}\text { Over-identification test } \mathrm{p} \text { - } \\
\text { value }\end{array}$ & & & & 0.98 & 0.99 & 0.78 & \\
\hline $\begin{array}{l}\text { F-test } \\
\text { instruments }(\text { Prob }>F)\end{array}$ & & & & & & & $\begin{array}{c}7.46 \\
(0.006)\end{array}$ \\
\hline Adjusted $\mathrm{R}^{2}$ & 0.84 & 0.77 & 0.96 & 0.88 & 0.79 & 0.90 & 0.79 \\
\hline Observations & 283 & 283 & 300 & 480 & 480 & 517 & 525 \\
\hline
\end{tabular}

Notes: Absolute t statistics calculated using robust standard errors are reported in parentheses, ${ }^{*}$ significant at $10 \%,{ }^{* *}$ significant at $5 \%,{ }^{* * *}$ significant at $1 \%$. For columns (1) - (3) we the average level of union membership (union members divided by population) before 1977 and use these data to match states that experience labor market reforms (pro-worker or pro-employer) with control states based on the level of unionization. We then regress labor regulation on the difference between registered manufacturing in a 'treatment' state and that in its matched 'control' state while also including match dummies in the regression. Standard errors in columns (4) - (6) are clustered at the state level. The two instruments for our lagged [t-1] labor regulation measure are: (i) the pre-1977 unionionization measure interacted with a post-1997 dummy and (ii) the proportion of constituent districts of modern states which operated non-landlord land revenue systems in British India interacted with a post-1977 dummy. The overidentification test we employ is due to Sargan [1958]. The number of observations times the $\mathrm{R}^{2}$ from the regression of the stage two residuals on the instruments is distributed $\chi^{2}(T+1)$ where $\mathrm{T}$ is the number of instruments. State amendments to the Industrial Disputes Act are coded $1=$ pro-worker, $0=$ neutral, $-1=$ pro-employer and then cumulated over the period to generate the labor regulation measure. Installed electrical capacity is measured in kilowatts and log development expenditure is real per capita state spending on social and economic services. The data are for the sixteen main states for the period 1958 - 1992. Haryana split from the Punjab in 1965 and, after this date, we include Haryana as a separate observation. We therefore have a total of 552 possible observations with deviations accounted for by missing data. See the Data Appendix for details on the construction and sources of the variables. 
Table 7 Labor Regulation and Industrial Performance in India: Industry Level Analysis 1980-1997

\begin{tabular}{|c|c|c|c|c|c|}
\hline & (1) & (2) & (3) & (4) & (5) \\
\hline & $\begin{array}{c}\text { Log registered } \\
\text { manufacturing } \\
\text { output }\end{array}$ & $\begin{array}{c}\text { Log registered } \\
\text { manufacturing } \\
\text { employment }\end{array}$ & $\begin{array}{l}\text { Log registered } \\
\text { fixed } \\
\text { capital }\end{array}$ & $\begin{array}{l}\text { Log number } \\
\text { factories }\end{array}$ & $\begin{array}{l}\text { Log value added } \\
\text { per employee }\end{array}$ \\
\hline Method & OLS & OLS & OLS & OLS & OLS \\
\hline Labor regulation $[\mathrm{t}-1]$ & $\begin{array}{c}-0.087 * * * \\
(3.68)\end{array}$ & $\begin{array}{c}-0.060 * * * \\
(3.19)\end{array}$ & $\begin{array}{c}-0.063^{*} \\
(1.86)\end{array}$ & $\begin{array}{c}-0.041 * * * \\
(2.86)\end{array}$ & $\begin{array}{c}-0.026 * * \\
(2.07)\end{array}$ \\
\hline State $*$ industry effects & YES & YES & YES & YES & YES \\
\hline Year effects & YES & YES & YES & YES & YES \\
\hline Industry time trends & YES & YES & YES & YES & YES \\
\hline Adjusted $\mathrm{R}^{2}$ & 0.90 & 0.90 & 0.81 & 0.92 & 0.74 \\
\hline Observations & 21323 & 21323 & 20539 & 21206 & 21254 \\
\hline
\end{tabular}

Notes: Absolute t statistics calculated using robust standard errors clustered at the state-industry level are reported in parentheses, $*$ significant at $10 \%$, $* *$ significant at 5\%,*** significant at $1 \%$. The data used in the regressions is a panel data set on 3 -digit registered manufacturing industries across the sixteen main states of India for the period 1980-1997. The data form an unbalanced panel. Our anlaysis retains state industries which remain in the panel for at least ten years and within these industries we restrict our attention to firms which employ more than a hundred workers to get around the problem of smaller firms being excluded from the sample to maintain confidentiality. Using this a definition we have total of 1013 -digit industries in our panel with an average of 68 in a each state. State amendments to the Industrial Disputes Act are coded 1=pro-worker, $0=$ neutral, $-1=$ pro-employer and then cumulated over the period to generate the labor regulation measure. The regressions include 3-digit industry time trends to help control for the possibility that industries experience different rates of technological change. See the Data Appendix for details on the construction and sources of the variables. 
Table 8 Labor Regulation and Poverty in India: 1958-1992

\begin{tabular}{|c|c|c|c|c|c|c|c|}
\hline & $(1)$ & $(2)$ & $(3)$ & $(4)$ & $(5)$ & $(6)$ & $(7)$ \\
\hline & $\begin{array}{c}\text { Overall } \\
\text { headcount }\end{array}$ & $\begin{array}{c}\text { Urban } \\
\text { headcount }\end{array}$ & $\begin{array}{c}\text { Rural } \\
\text { headcount }\end{array}$ & $\begin{array}{c}\text { Urban } \\
\text { headcount }\end{array}$ & $\begin{array}{c}\text { Urban } \\
\text { headcount }\end{array}$ & $\begin{array}{c}\text { Urban } \\
\text { headcount }\end{array}$ & $\begin{array}{c}\text { Urban } \\
\text { headcount }\end{array}$ \\
\hline Method & OLS & OLS & OLS & OLS & $\begin{array}{c}\text { OLS } \\
\text { [state time } \\
\text { trends] }\end{array}$ & $\begin{array}{c}\text { OLS } \\
\text { [survey years } \\
\text { only] }\end{array}$ & $\begin{array}{c}\text { OLS } \\
{[\text { no West }} \\
\text { Bengal] }\end{array}$ \\
\hline Labor regulation[t-1] & $\begin{array}{l}-0.008 \\
(0.01)\end{array}$ & $\begin{array}{l}2.288 * * * \\
(3.31)\end{array}$ & $\begin{array}{l}-0.821 \\
(0.48)\end{array}$ & $\begin{array}{c}2.070 * * \\
(2.52)\end{array}$ & $\begin{array}{l}-0.270 \\
(0.30)\end{array}$ & $\begin{array}{c}2.251 * * \\
(2.52)\end{array}$ & $\begin{array}{l}1.916^{* *} \\
(1.99)\end{array}$ \\
\hline $\begin{array}{l}\text { Log develop } \\
\text { expenditure per capita }\end{array}$ & & & & $\begin{array}{l}-3.468 \\
(0.82)\end{array}$ & $\begin{array}{l}-0.983 \\
(0.32)\end{array}$ & $\begin{array}{r}-2.900 \\
(0.79)\end{array}$ & $\begin{array}{r}-4.044 \\
(0.94)\end{array}$ \\
\hline $\begin{array}{l}\text { Log installed } \\
\text { electricity capacity } \\
\text { per capita }\end{array}$ & & & & $\begin{array}{l}0.242 \\
(0.28)\end{array}$ & $\begin{array}{l}1.260 \\
(1.60)\end{array}$ & $\begin{array}{l}1.058 \\
(1.02)\end{array}$ & $\begin{array}{l}0.875 \\
(1.27)\end{array}$ \\
\hline Log state population & & & & $\begin{array}{l}-5.448 \\
(0.29)\end{array}$ & $\begin{array}{l}38.74 \\
(1.28)\end{array}$ & $\begin{array}{l}-3.717 \\
(0.19)\end{array}$ & $\begin{array}{r}-10.42 \\
(0.56)\end{array}$ \\
\hline Congress majority & & & & $\begin{array}{c}0.418 * * \\
(1.98)\end{array}$ & $\begin{array}{l}0.206 \\
(0.63)\end{array}$ & $\begin{array}{c}0.464 * * \\
(2.36)\end{array}$ & $\begin{array}{c}0.452 * * \\
(1.99)\end{array}$ \\
\hline Hard left majority & & & & $\begin{array}{c}0.508^{*} \\
(1.76)\end{array}$ & $\begin{array}{l}-0.083 \\
(0.21)\end{array}$ & $\begin{array}{l}0.501 \\
(1.46)\end{array}$ & $\begin{array}{l}0.306 \\
(0.39)\end{array}$ \\
\hline Janata majority & & & & $\begin{array}{l}0.518 \\
(1.14)\end{array}$ & $\begin{array}{l}0.819 \\
(1.28)\end{array}$ & $\begin{array}{l}0.326 \\
(0.73)\end{array}$ & $\begin{array}{l}0.557 \\
(1.19)\end{array}$ \\
\hline Regional majority & & & & $\begin{array}{c}0.463 * * * \\
(2.86)\end{array}$ & $\begin{array}{l}0.439 \\
(0.90)\end{array}$ & $\begin{array}{c}0.504 * * * \\
(2.76)\end{array}$ & $\begin{array}{c}0.487 * * * \\
(2.86)\end{array}$ \\
\hline State effects & YES & YES & YES & YES & YES & YES & YES \\
\hline Year effects & YES & YES & YES & YES & YES & YES & YES \\
\hline Adjusted $\mathrm{R}^{2}$ & 0.83 & 0.88 & 0.80 & 0.89 & 0.91 & 0.87 & 0.89 \\
\hline Observations & 547 & 547 & 547 & 518 & 518 & 311 & 485 \\
\hline
\end{tabular}

Notes: Absolute $t$ statistics calculated using robust standard errors clustered at the state level are reported in parentheses, $*$ significant at $10 \%, * *$ significant at $5 \%, * * *$ significant at $1 \%$. Poverty headcount is the percentage of the population below the official Indian poverty lines which are separately defined for rural and urban areas. In column (4) the rural-urban poverty difference is the difference between the rural and urban headcount measures for each state. In column (7) we only include data for years when National Sample Surveys were carried out. State amendments to the Industrial Disputes Act are coded 1=pro-worker, $0=$ neutral, $-1=$ pro-employer and then cumulated over the period to generate the labor regulation measure. Installed electrical capacity is measured in kilowatts and development expenditure is real per capita state spending on social and economic services. Congress, hard left, Janata and regional majority are counts of the number of years for which these political groupings held a majority of the seats in the state legislatures. The data are for the sixteen main states for the period 1958 - 1992. Haryana split from the Punjab in 1965 and, after this date, we include Haryana as a separate observation. We therefore have a total of 552 possible observations with deviations accounted for by missing data. See the Data Appendix for details on the construction and sources of the variables. 
Appendix Table: Regulatory Change in India: 1958 - 1992

\begin{tabular}{|c|c|c|c|}
\hline State & Change Year & Amendments and codes & Overall Code \\
\hline \multirow[t]{3}{*}{ Andhra Pradesh } & 1968 & Limits strikes and lockouts in designated public utilities [-1]. & Pro-employer \\
\hline & 1982 & Facilitates settlement of industrial disputes in labor courts [-1] & Pro-employer \\
\hline & 1987 & $\begin{array}{l}\text { Prohibits strikes and lockouts when in the public interest [-1]. Workers have to be paid before closing } \\
\text { down firm [1]. Prior workers given preference when rehiring [1]. Dismissed workers paid from } \\
\text { reinstatement not rehiring date [1]. Imposes penalty for not complying with order prohibiting industrial } \\
\text { disputes [-1]. Individual workers can apply to labor court for adjudication [1]. Widens judicial powers to } \\
\text { recover money owed to workers by employer [1]. Lengthens the notice employer must give worker about } \\
\text { change in conditions of service [1]. }\end{array}$ & Pro-worker \\
\hline Gujarat & 1973 & Imposes penalty on employer for not nominating representatives to councils within firms [1]. & Pro-worker \\
\hline Karnataka & 1988 & $\begin{array}{l}\text { Individual workers can apply to labor court for adjudication [1]. Enforces attendance at industrial dispute } \\
\text { hearings [-1]. Empowers state governments to transfer disputes across tribunals to facilitate settlement [-1]. } \\
\text { Prohibits strikes and lockouts when in the public interest [-1]. Extends rules for layoff, retrenchment and } \\
\text { closure to smaller firms [1]. }\end{array}$ & Pro-employer \\
\hline Kerala & 1979 & $\begin{array}{l}\text { Prohibits strikes and lockouts when in the public interest [-1]. Imposes penalty for not complying with } \\
\text { order prohibiting industrial disputes [-1]. }\end{array}$ & Pro-employer \\
\hline \multirow[t]{2}{*}{$\begin{array}{l}\text { Madhya } \\
\text { Pradesh }\end{array}$} & 1982 & $\begin{array}{l}\text { Extends powers of labor courts to settle industrial disputes. [-1]. Facilitates settlement of industrial disputes } \\
\text { in labor courts [-1] }\end{array}$ & Pro-employer \\
\hline & 1983 & Applies closure rules to previously uncovered undertakings [1]. & Pro-worker \\
\hline \multirow[t]{2}{*}{ Maharashtra } & 1981 & $\begin{array}{l}\text { Compensation now received for closure due to lay-off [1]. Workers receive } 100 \% \text { as opposed to } 50 \% \text { of } \\
\text { wages for layoff due to electricity problems [1]. Extends rules for layoff, retrenchment and closure to } \\
\text { smaller firms [1]. }\end{array}$ & Pro-worker \\
\hline & 1983 & Gives power of appeal to workers to overturn decision to close down firm [1]. & Pro-worker \\
\hline Orissa & 1983 & $\begin{array}{l}\text { Extends rules for layoff, retrenchment and closure to smaller firms [1]. Gives power of appeal to workers } \\
\text { to overturn decision to close down firm [1]. }\end{array}$ & Pro-worker \\
\hline \multirow[t]{3}{*}{ Rajasthan } & 1960 & $\begin{array}{l}\text { Exact criteria for being union member defined [-1]. Defines employers in firms sub-contracted to industry } \\
\text { as employers for industrial disputes purposes [1]. Defines who is allowed to be involved in bargaining } \\
\text { process on behalf of unions [-1]. Gives definition of what a union is in an industrial dispute [-1]. Definition } \\
\text { of worker for industrial disputes purposes extends to those subcontracted with an industry [1]. }\end{array}$ & Pro-employer \\
\hline & 1970 & $\begin{array}{l}\text { Empowers the states to refer industrial disputes to industrial tribunals when it is in the public interest [-1]. } \\
\text { Prohibits strikes and lockouts when in the public interest [-1]. Imposes penalty for not complying with } \\
\text { order prohibiting industrial disputes [-1]. Widens judicial powers to recover money owed to workers by } \\
\text { employer [1]. Defines union registration rules to prevent multiple representation [-1]. }\end{array}$ & Pro-employer \\
\hline & 1984 & $\begin{array}{l}\text { Extends rules for layoff, retrenchment and closure to smaller firms [1]. Can continue lay-offs due to natural } \\
\text { disasters for more than } 30 \text { days without permission [-1]. Union representative has to be involved in } \\
\text { negotiations concerning retrenchment of workers [1]. Applies closure rules to previously uncovered } \\
\text { undertakings [1]. Increases penalty for unauthorized layoff and retrenchment of workers [1]. Extends rules } \\
\text { for layoff, retrenchment and closure to smaller firms [1]. }\end{array}$ & Pro-worker \\
\hline
\end{tabular}




\begin{tabular}{|c|c|c|c|}
\hline Tamil Nadu & 1982 & $\begin{array}{l}\text { Prohibits strikes and lockouts when in the public interest [-1]. Imposes penalty for not complying with } \\
\text { order prohibiting industrial disputes [-1]. }\end{array}$ & Pro-employer \\
\hline \multirow[t]{4}{*}{ West Bengal } & 1974 & Prohibits lay-off of worker given employment on same day [1]. & Pro-worker \\
\hline & 1980 & $\begin{array}{l}\text { Includes workers involved in sales in definition of worker [1]. Retrenchment does include workers } \\
\text { terminated on grounds of ill-health [1]. Extends period within which report of conciliation proceedings } \\
\text { must be submitted [1]. Extends date at which conciliation proceedings are deemed to have started [1]. } \\
\text { Facilitates settlement of industrial disputes in labor courts [-1]. Facilitates the making of awards by labor } \\
\text { courts [1]. Limit on the number of days laid off workers receive } 50 \% \text { of their wages is removed [1]. Laid } \\
\text { off worker only have to present themselves once a week at the plant if lay off extends for more than seven } \\
\text { days [1]. Workers have to be paid before closing down firm [1]. Prior workers given preference when } \\
\text { rehiring [1]. Dismissed workers paid from reinstatement not rehiring date [1]. Extends rules for layoff, } \\
\text { retrenchment and closure to smaller firms [1]. Extends period after which employer can commence lay-off } \\
\text { [1]. Widens judicial powers to recover money owed to workers by employer [1]. Lengthens the notice } \\
\text { employer must give worker about change in conditions of service [1]. }\end{array}$ & Pro-worker \\
\hline & 1986 & $\begin{array}{l}\text { Makes transparent the award procedures to be followed and relief to be given to discharged, dismissed or } \\
\text { retrenched workers. }\end{array}$ & Pro-worker \\
\hline & 1989 & $\begin{array}{l}\text { Individual workers can apply directly to conciliation officer and labor court for adjudication [1]. } \\
\text { Employers have to demonstrate ability to pay compensation to pay workers before closing down firm [1]. } \\
\text { Refusal of employment is grounds for an individual worker to enter into an industrial dispute [1]. }\end{array}$ & Pro-worker \\
\hline
\end{tabular}

http://econ.lse.ac.uk/staff/rburgess/wp. 


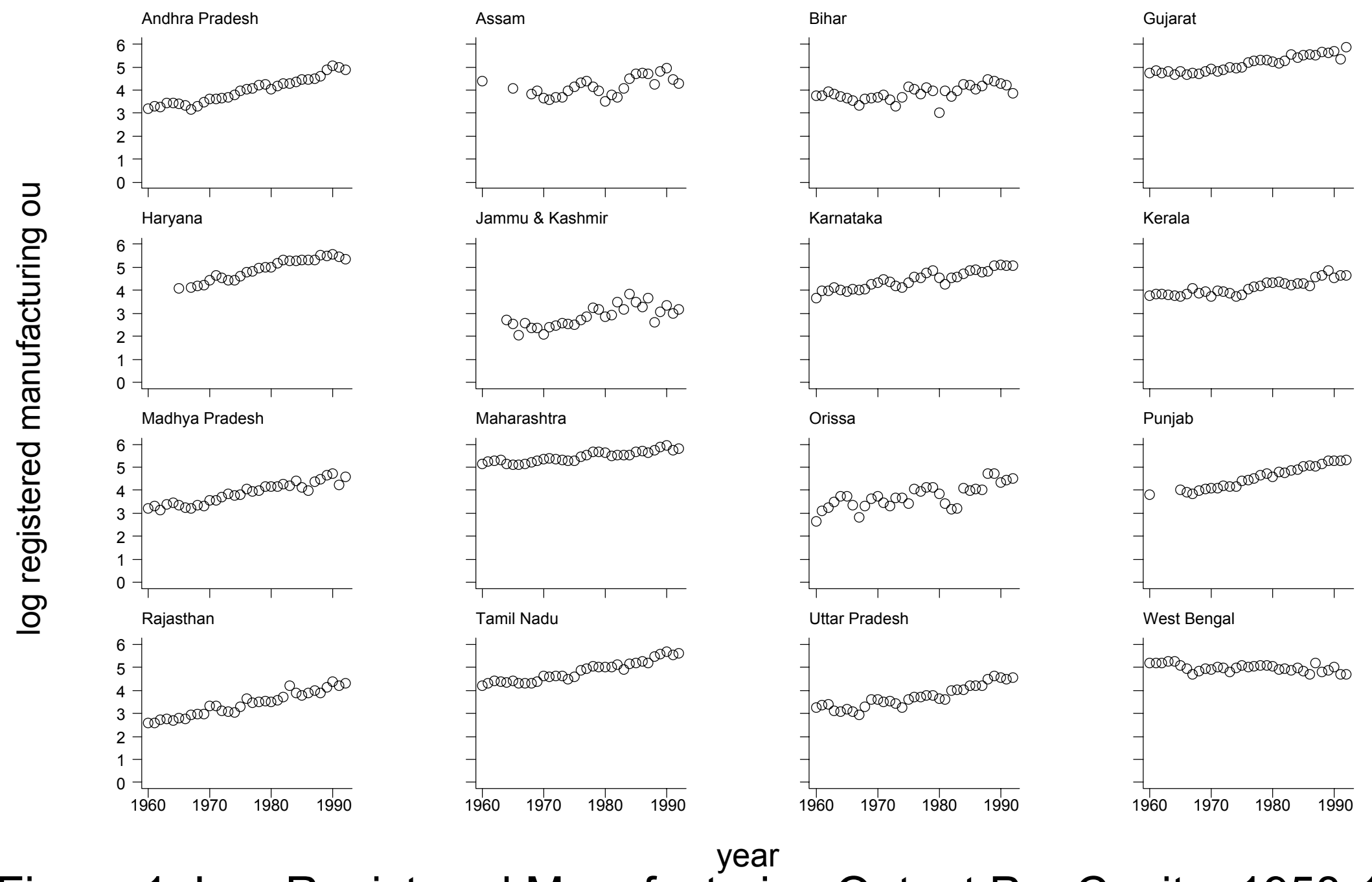

Figure 1: Log Registered Manufacturing Output Per Capita: 1958-1992 


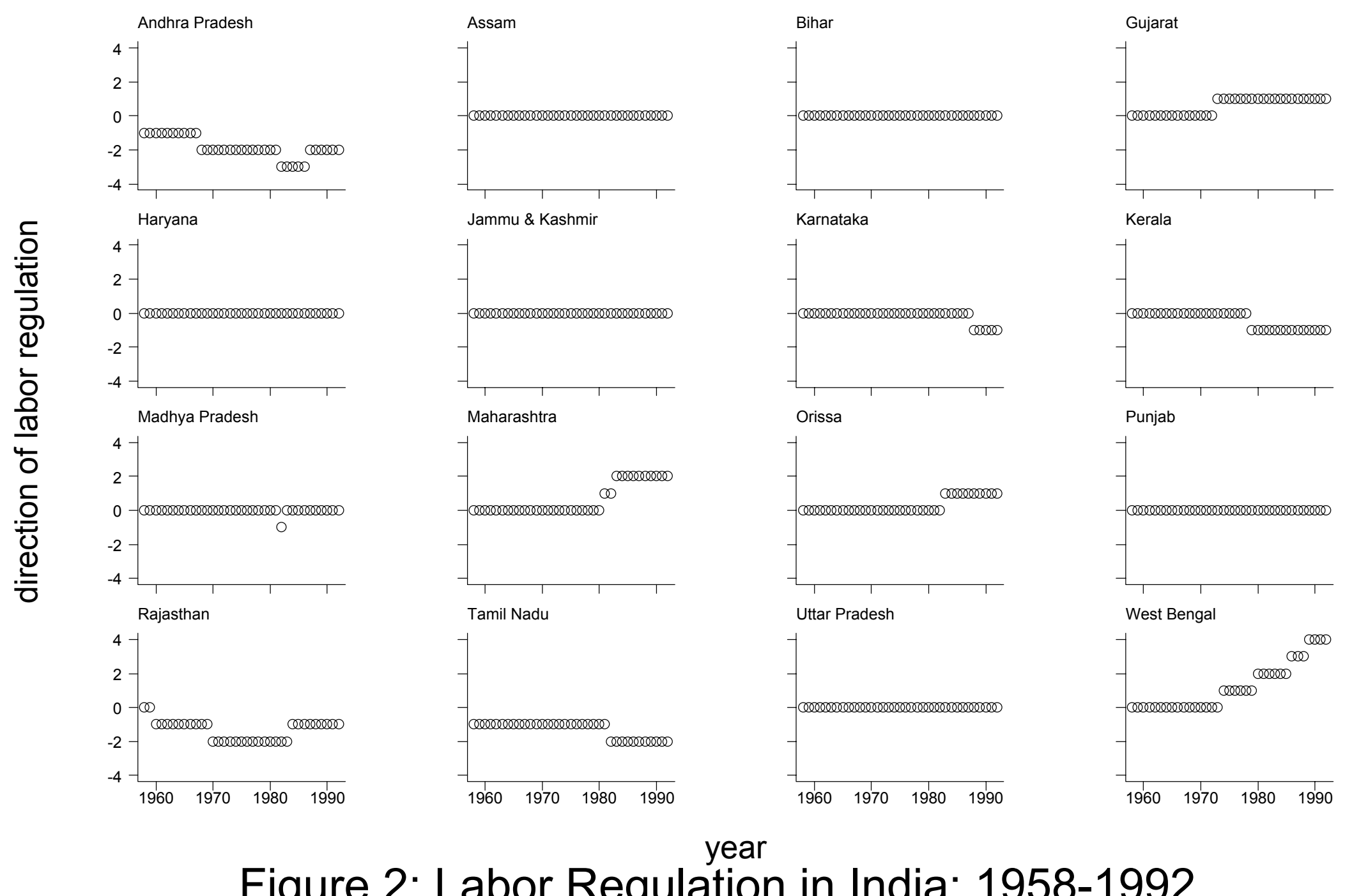

Figure 2: Labor Regulation in India: 1958-1992 